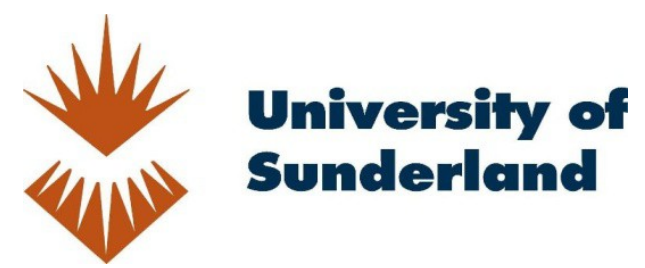

Gartlon, J, Szekeres, P, Pullen, M, Sarau, HM, Aiyar, N, Shabon, U, Michalovich, D, Steplewski, K, Ellis, C, Elshourbagy, N, Duxon, M, Ashmeade, TE, Harrison, DC, Murdock, P, Wilson, S, Ennaceur, Abdelkader, Atkins, A, Heidbreder, C, Hagan, JJ, Hunter, AJ and Jones, DNC (2004) Localisation of NMU1R and NMU2R in human and rat central nervous system and effects of neuromedin-U following central administration in rats. Psychopharmacology, 177. pp. 1-14. ISSN 0033-3158

Downloaded from: http://sure.sunderland.ac.uk/id/eprint/5958/ 
Please refer to the usage guidelines at http://sure.sunderland.ac.uk/policies.html or alternatively contact sure@sunderland.ac.uk. 
Jane Gartlon • Philip Szekeres • Mark Pullen · Henry M. Sarau • Nambi Aiyar •

Usman Shabon · David Michalovich · Klaudia Steplewski • Cathy Ellis •

Nabil Elshourbagy • Mark Duxon · Tracey E. Ashmeade • David C. Harrison •

Paul Murdock - Shelagh Wilson - Abdel Ennaceur - Alan Atkins ·

Christian Heidbreder · Jim J. Hagan - A. Jackie Hunter - Declan N. C. Jones

\section{Localisation of NMU1R and NMU2R in human and rat central nervous system and effects of neuromedin- $U$ following central administration in rats}

Received: 28 February 2003 / Accepted: 30 March 2004 / Published online: 16 June 2004

(C) Springer-Verlag 2004

\begin{abstract}
Rationale: Neuromedin-U (NmU) is an agonist at NMU1R and NMU2R. The brain distribution of NmU and its receptors, in particular NMU2R, suggests widespread central roles for NmU. In agreement, centrally administered $\mathrm{NmU}$ affects feeding behaviour, energy expenditure and pituitary output. Further central nervous system (CNS) roles for $\mathrm{NmU}$ warrant investigation. Objectives: To investigate the CNS role of $\mathrm{NmU}$ by mapping NMU1R and NMU2R mRNA and measuring the behavioural, endocrine, neurochemical and c-fos response to intracerebroventricular (i.c.v.) NmU. Methods: Binding affinity and functional potency of rat $\mathrm{NmU}$ was determined at human NMU1R and NMU2R. Expression of NMU1R and NMU2R mRNA in rat and human tissue was determined using semi-quantitative reverse-transcription polymerase chain reaction. In in-vivo studies, $\mathrm{NmU}$
\end{abstract}

J. Gartlon $(\bowtie) \cdot$ A. Ennaceur $\cdot$ A. Atkins $\cdot$ C. Heidbreder . J. J. Hagan · D. N. C. Jones

Psychiatry Centre of Excellence for Drug Discovery,

GlaxoSmithKline plc,

New Frontiers Science Park, Third Avenue,

Harlow, CM19 5AW, Essex, United Kingdom

e-mail: jane.gartlon@gsk.com

Tel.: +44-1279-622509

P. Szekeres · M. Duxon · T. E. Ashmeade · D. C. Harrison · A. J. Hunter

Neurology and GI Centre of Excellence for Drug Discovery, GlaxoSmithKline plc,

New Frontiers Science Park, Third Avenue,

Harlow, Essex, United Kingdom, CM19 5AW

M. Pullen · H. M. Sarau · N. Aiyar · U. Shabon ·

D. Michalovich · K. Steplewski · P. Murdock - S. Wilson

Systems Research, GlaxoSmithKline plc,

New Frontiers Science Park, Third Avenue,

Harlow, Essex, United Kingdom, CM19 5AW

C. Ellis · N. Elshourbagy

Genetics Research, GlaxoSmithKline plc,

Upper Merion,

King of Prussia, PA 19406, USA was administered i.c.v. to male Sprague-Dawley rats, and changes in grooming, motor activity and pre-pulse inhibition (PPI) were assessed. In further studies, plasma endocrine hormones, [DOPAC $+\mathrm{HVA}] /[$ dopamine] and [5-HIAA $] /[5-\mathrm{HT}]$ ratios and levels of Fos-like immunoreactivity (FLI) were measured $20 \mathrm{~min}$ post-NmU (i.c.v.). Results: $\mathrm{NmU}$ bound to NMU1R $\left(K_{\mathrm{I}}, 0.11 \pm 0.02 \mathrm{nM}\right)$ and NMU2R $\left(K_{\mathrm{I}}, 0.21 \pm 0.05 \mathrm{nM}\right)$ with equal affinity and was equally active at NMU1R $\left(\mathrm{EC}_{50}, 1.25 \pm 0.05 \mathrm{nM}\right)$ and NMU2R $\left(\mathrm{EC}_{50}, 1.10 \pm 0.20 \mathrm{nM}\right)$ in a functional assay. NMU2R mRNA expression was found at the highest levels in the CNS regions of both rat and human tissues. NMU1R mRNA expression was restricted to the periphery of both species with the exception of the rat amygdala. NmU caused a marked increase in grooming and motor activity but did not affect PPI. Further, NmU decreased plasma prolactin but did not affect levels of corticosterone, luteinising hormone or thyroid stimulating hormone. $\mathrm{NmU}$ elevated levels of 5-HT in the frontal cortex and hypothalamus, with decreased levels of its metabolites in the hippocampus and hypothalamus, but did not affect dopamine function. NmU markedly increased FLI in the nucleus accumbens, frontal cortex and central amygdala. Conclusions: These data provide further evidence for widespread roles for $\mathrm{NmU}$ and its receptors in the brain.

Keywords Neuromedin-U (NmU) · NMU2R · NMU1R · Grooming · Prolactin · 5-HT · Fos · RT-PCR

\section{Introduction}

The neuromedins are a family of neuropeptides best known for their smooth muscle stimulating activity (Minamino et al. 1985). Neuromedin-U (NmU) was originally isolated from porcine spinal cord by Minamino et al. (1985) and was subsequently isolated from a variety of species including rat (NmU-23), human (NmU-25) and frog (NmU-25) (Conlon et al. 1988; Domin et al. 1989; 
O'Harte et al. 1991). The core active sequence (Phe-LeuPhe-Arg-Pro-Arg-Asn-NH2) lies between residues 2 and 8 and is common to mammalian species (Hashimoto et al. 1991; Sakura et al. 1991).

NmU-like immunoreactivity (NmU-ir) is present in the gastrointestinal and urogenital tracts, and in parts of the central nervous system (CNS). In rat brain, the highest levels of NmU-ir are found in the nucleus accumbens, hypothalamus, anterior pituitary and thalamus (Domin et al. 1986, 1987). NmU-immunoreactive cell bodies are confined to the rostrocaudal part of the arcuate nucleus with a more widespread distribution of immunoreactive fibres in the nucleus accumbens, medial thalamus and brain stem, and in the paraventricular (PVN), ventromedial, dorsomedial and arcuate nuclei of the hypothalamus (Ballesta et al. 1988; Steel et al. 1988). In contrast, in-situ hybridisation showed discrete localisation of NmU mRNA in the pituitary pars tuberalis and not in the arcuate nucleus (Ivanov et al. 2002).

An orphan G-protein coupled receptor (GPCR) termed NMU1R [previously termed FM-3 (Tan et al. 1998)] was recently identified as a receptor for $\mathrm{NmU}$ (Fujii et al. 2000; Szekeres et al. 2000; Hedrick et al. 2000; Howard et al. 2000; Kojima et al. 2000). In our own group, NmU-23 was identified as an agonist $\left(\mathrm{EC}_{50}, 0.17 \pm 0.02 \mathrm{nM}\right)$ for NMU1R transiently expressed in HEK 293 cells, by measuring intracellular calcium mobilisation in response to a large library of putative GPCR ligands (Szekeres et al. 2000). NMU1R is expressed in a variety of human and rat peripheral tissues, including lung and small intestine (Fujii et al. 2000; Szekeres et al. 2000; Howard et al. 2000) but has not previously been detected in the human or rat brain (Howard et al. 2000).

A second receptor for $\mathrm{NmU}$, the novel orphan receptor FM-4 (Howard et al. 2000), was subsequently described by several groups (Howard et al. 2000; Shan et al. 2000; Hosoya et al. 2000; Raddatz et al. 2000). In agreement, each group reported an $\mathrm{EC}_{50}$ of 1-5 $\mathrm{nM}$ for activation of FM-4 by NmU in functional assays measuring $\mathrm{Ca}^{2+}$ mobilisation. This receptor was termed NMU2R (Howard et al. 2000). In contrast with NMU1R localisation, NMU2R expression is mostly restricted to specific regions of the brain. Using in situ hybridisation, rat NMU2R is detected in the PVN, the wall of the third ventricle in the hypothalamus and in the CA1 region of the hippocampus (Howard et al. 2000). Expression in the periphery is also reported; for example, Hosoya et al. (2000) found significant NMU2R expression in the uterus, lung and ovary. In humans, Raddatz et al. (2000) reported relatively high levels of NMU2R mRNA in the medulla oblongata, pontine reticular formation, spinal cord and thalamus. However, Howard et al. (2000) could detect only weak human brain expression of NMU2R using Northern analysis. In the periphery, human NMU2R mRNA is detected in the kidney, lung (Shan et al. 2000; Raddatz et al. 2000), trachea, testis (Raddatz et al. 2000) and thyroid tissue (Shan et al. 2000).

Despite the widespread distribution of $\mathrm{NmU}$ and its receptors, the physiological role of $\mathrm{NmU}$ is poorly understood. Until recently, studies have been hampered by the lack of known cognate receptor(s). However, it was found that systemic $\mathrm{NmU}$ causes contraction of smooth muscle, increases arterial blood pressure, modifies intestinal blood flow and ion transport, and increases adenocorticotrophic hormone (ACTH) and blood corticosterone (Brown and Quito 1988; Sumi et al. 1987; Gardiner et al. 1990; Malendowicz and Markowska 1994). Consistent with the brain localisation of $\mathrm{NmU}$ and its receptors, $\mathrm{NmU}$ also acts centrally to decrease fastinduced and overnight food intake and gastric acid secretion (Mondal et al. 2003), with an increase in body temperature, oxygen consumption and locomotor activity (Howard et al. 2000; Kojima et al. 2000; Nakazato et al. 2000; Hanada et al. 2001; Ivanov et al. 2002; Wren et al. 2002).

Intracerebroventricular (i.c.v.) injection of $\mathrm{NmU}$ increases release of ACTH, AVP and corticosterone, suggesting a role in regulation of the hypothalamopituitary-adrenal axis (HPA) (Ozaki et al. 2002; Wren et al. 2002). Consistent with these effects, NmU increases cfos expression in the corticotrophin-releasing hormone (CRH)-containing parvocellular regions of the PVN and supraoptic nuclei of the hypothalamus (Ozaki et al. 2002; Ivanov et al. 2002). CRH acts primarily to control ACTH release from the pituitary gland but has additional effects in the brain. Central administration of $\mathrm{CRH}$ activates motor activity and grooming behaviour and reduces food intake (Morley and Levine 1982; Jones et al. 1998). Given that the central effects of CRH appear similar to those observed following $\mathrm{NmU}$, and that $\mathrm{NmU}$-induced changes in feeding behaviour, energy expenditure and motor activity are absent in the CRH knockout mouse (Hanada et al. 2001, 2003), it is speculated that the primary role for $\mathrm{NmU}$ is in regulation of the stress response via interaction with CRH. However, the widespread distribution of $\mathrm{NmU}$ fibres within and outside of the hypothalamus suggests further central roles for NmU. Indeed, $\mathrm{NmU}$ affects the release of oxytocin (Ozaki et al. 2002) and was recently found to be pro-nociceptive in both rats and mice (Yu et al. 2003; Cao et al. 2003).

Therefore, the aims of this study were to further characterise the central effects of $\mathrm{NmU}$ on behaviours, determine effects on various neuroendocrine hormones and, importantly, to investigate regions of the brain and neurotransmitters involved in mediating NmU-induced changes. In order to address discrepancies in previous reports of receptor distribution, polymerase chain reaction with reverse transcription (RT-PCR) was used to measure expression of NMU1R and NMU2R mRNA in rat and human tissues. Initial behavioural profiling revealed that central administration of $\mathrm{NmU}$ stimulated a prominent behavioural syndrome characterised by a marked grooming response. Given the stimulant-like effect of $\mathrm{NmU}$ on behaviours, effects on pre-pulse inhibition (PPI) of an acoustic startle stimulus were determined. Following these observations, investigation of effects on a range of neuroendocrine hormones revealed decreased levels of prolactin. In determining the basis of these changes, 
neurochemical assessment, which determined the effects of $\mathrm{NmU}$ on dopamine (DA) and serotonin (5-hydroxytryptamine; 5-HT) systems, revealed altered 5-HT neurotransmission mainly in the frontal cortex and hypothalamus. Finally, to investigate anatomical substrates for these and other effects of NmU, we measured the induction of cfos in a range of brain regions to map NmU-induced neuronal activation.

\section{Materials and methods}

Radioligand binding assay

\section{Membrane preparation}

HEK293 cells were detached from $150-\mathrm{cm}^{2}$ flasks with $1 \mathrm{mM}$ ethylene diamine tetraacetic acid (EDTA) in $\mathrm{Ca} / \mathrm{Mg}$-free Dulbecco's phosphate-buffered saline (DPBS), washed by centrifugation at $300 \times g$ and stored as a frozen pellet. The cells were suspended in icecold buffer containing $10 \mathrm{mM}$ Tris- $\mathrm{HCl}(\mathrm{pH}$ 7.4), $5 \mathrm{mM}$ Na-EDTA, $0.1 \mathrm{mM}$ phenylmethylsulphonylfluoride, $1.0 \mathrm{mg} / \mathrm{ml}$ bacitracin and $0.1 \mathrm{mg} / \mathrm{ml}$ aprotinin (buffer A) and homogenized using a Dounce homogenizer. The homogenates were centrifuged at $47,000 \times g$ for $20 \mathrm{~min}$ at $4^{\circ} \mathrm{C}$ and the membrane pellets were washed twice by centrifugation in buffer containing $20 \mathrm{mM}$ Tris- $\mathrm{HCl}(\mathrm{pH} 7.4), 5 \mathrm{mM}$ $\mathrm{MgCl}_{2}, 2 \mathrm{mM}$ Na-ethylene glycol tetraacetic acid (Na-EGTA) and $0.1 \mathrm{mg} / \mathrm{ml}$ bacitracin (buffer B). The final pellet was re-suspended in buffer B (at $2 \mathrm{mg} / \mathrm{ml}$ ) and stored as aliquots frozen at $-70^{\circ} \mathrm{C}$. The protein concentration was measured using the Pierce BCA method with bovine serum albumin as a standard.

\section{Radioligand binding assay}

Membranes (30-50 $\mu \mathrm{g} / \mathrm{ml}$ of membrane proteins) in buffer B were incubated with $\left[{ }^{125} \mathrm{I}\right]$ porcine $\mathrm{NmU}(120-150 \mathrm{pM})$ in a total volume of $200 \mu \mathrm{l}$ for $60 \mathrm{~min}$ at $25^{\circ} \mathrm{C}$. Non-specific binding, assessed in the presence of unlabelled porcine NmU-25 $(1 \mu \mathrm{M})$, represented less than $1 \%$, with total binding representing $9 \pm 0.5 \%$ of radioligand in the incubation. The reaction was terminated by the addition of $3 \mathrm{ml}$ ice-cold $0.9 \% \mathrm{NaCl}$ followed by rapid filtration through a Skatron cell harvester with glass fiber filter mats that had been soaked in $0.3 \%$ polyethyleneimine. Filters were counted in a Packard Cobra II $\gamma$ counter. All binding assays were done in duplicate, and each experiment was repeated four to five times. Analyses of all binding data $\left(K_{\mathrm{I}}\right.$ values) were performed by computer-assisted non-linear least-square fitting using GRAPHPAD PRISM (Graphpad Software, Inc., San Diego). Rat NmU was purchased from Bachem Biochemicals (King of Prussia, PA). Radiolabelled $\left[{ }^{125} \mathrm{I}\right]$ porcine NmU-25 (specific activity $2000 \mathrm{Ci} / \mathrm{mmol}$ ) was a generous gift from New England Nuclear (Boston, MA).

\section{Calcium mobilisation assays}

HEK-293 cells transiently expressing human NMU1R or human NMU2R were seeded into poly-D-lysine coated 384-well black-wall, clear-bottom microtitre plates (Becton Dickinson) $24 \mathrm{~h}$ prior to assay. Cells were loaded for $1 \mathrm{~h}$ with $1 \mu \mathrm{M}$ Fluo-4-AM fluorescent indicator dye (Molecular Probes) in assay buffer (Hanks Balanced Salts Solution [HBSS], $10 \mathrm{mM}$ HEPES, $200 \mu \mathrm{M} \mathrm{Ca}^{2+}, 0.1 \%$ BSA, $2.5 \mathrm{mM}$ probenecid), washed three times with assay buffer, then returned to the incubator for $10 \mathrm{~min}$ before assay on a fluorometric imaging plate reader (FLIPR, Molecular Devices). Maximum change in fluorescence over baseline was used to determine agonist response. Concentration response curve data were fitted to a four- parameter logistic equation using GraFit (Erithacus Software Limited).

\section{Quantitative RT-PCR analysis}

For TaqMan RT-PCR mRNA localisation studies in rats, SpragueDawley rats (300-350 g) were killed by $\mathrm{CO}_{2}$ asphyxia followed by cervical dislocation. Tissues were dissected free, and the brain was further sub-divided into 15 regions. Each tissue was pooled from 6 16 rats, depending on the size of the individual tissue samples obtained. Human tissue or non-pooled RNA was purchased from Biochain (San Leandro, CA, USA), Invitrogen (Leek, The Netherlands), Clontech (Palo Alto, CA, USA) or donated from the Netherlands Brain Bank (Amsterdam).

Total RNA was extracted from the tissue using TRIzol reagent (Life Technologies), according to the manufacturer's suggested protocol, with the addition of an extra chloroform extraction step and phase separation, and an extra wash of the isolated RNA in $70 \%$ ethanol. The RNA was re-suspended in autoclaved, ultra pure water and the concentration calculated by $\mathrm{A}_{260}$ measurement. RNA quality was assessed by electrophoresis on a $1 \%$ agarose gel. For human samples, poly A + RNA was further purified from total RNA by the PolyATract method according to manufacturer's instructions (Promega, USA) and RNA was re-suspended and its concentration quantified as described above.

First-strand cDNA synthesis was carried out by oligo(dT) priming of $1 \mu \mathrm{g}$ of each total RNA sample or by random priming of each $1 \mu \mathrm{g}$ polyA + RNA sample [0.01 M DTT, $0.5 \mathrm{mM}$ each dNTP, $0.5 \mu \mathrm{g}$ oligo $(\mathrm{dT})$ primer or $0.15 \mu \mathrm{g}$ random 9-mer, $40 \mathrm{U}$ RNAseOUT ribonuclease inhibitor (Life Technologies) $200 \mathrm{U}$ Superscript II reverse transcriptase (Life Technologies)]. For rat samples, triplicate RT reactions were performed along with an additional reaction in which the reverse transcriptase was omitted to allow for assessment of genomic DNA contamination of the RNA. For human samples, RNA samples from four non-diseased individuals (two males, two females) per tissue were treated separately as above. The resulting cDNA products were divided into 20 aliquots (rat samples) or 1000 aliquots (human samples) for parallel TaqMan PCR reactions using different primer and probe sets for quantification of multiple cDNA sequences.

Quantitative RT-PCR was carried out using an ABI 7700 sequence detector (Perkin Elmer) on the cDNA samples $[2.5 \mathrm{mM}$ $\mathrm{MgCl}_{2}, 0.2 \mathrm{mM}$ dATP, dCTP, dGTP and dUTP, $0.1 \mu \mathrm{M}$ each primer, $0.05 \mu \mathrm{M}$ Taqman probe, $0.01 \mathrm{U}$ AmpErase uracil- $N$-glycosylase (Perkin Elmer), 0.0125 U Amplitaq Gold DNA polymerase (Perkin Elmer); $50^{\circ} \mathrm{C}$ for $2 \mathrm{~min}, 95^{\circ} \mathrm{C}$ for $10 \mathrm{~min}$ followed by 40 cycles of $95^{\circ} \mathrm{C}$ for $15 \mathrm{~s}, 60^{\circ} \mathrm{C}$ for $1 \mathrm{~min}$ ]. Additional reactions were performed on each 96-well plate using known dilutions of either rat or human genomic DNA as a PCR template to allow construction of a standard curve relating threshold cycle to template copy number.

TaqMan primer and probe sets for rat and human NMU1R and NMU2R and for the housekeeping gene $\beta$-actin were designed from sequences in the Genbank database using Primer Express V1.0 software (Perkin Elmer). Levels of mRNA measured were calculated as copies of mRNA detected per nanogram total RNA (rat) or per nanogram polyA + RNA (human).

The primer and probe sequences (forward primer, reverse primer and TaqMan probe)are shown here for rat and human.

- Rat

\section{- NMU1R}

- Forward primer: CTGCCCATGGTCACCATCA

- Reverse primer: AACATCCTCTCCCTCCGCA

- TaqMan probe: TCAGCCCAATGAGCAGGTACAGCACA

\section{- NMU2R}

- Forward primer: TGCTGTTTGTCTTGGTCCTCG

- Reverse primer: AAAGCTGAAGAAGAGCCGGTC 
- TaqMan probe: TTTGCCATCTGCTGGACCCCCTTC

- $\beta$-Actin:

- Forward primer: TCTGTGTGGATTGGTGGCTCTA

- Reverse primer: CTGCTTGCTG ATCCACATCTG

- TaqMan probe: CCTGGCCTCACTGTCCACCTTCC

- Human

- NMUR1

- Forward primer: GGCTCCAGCAGCACGATC

- Reverse primer: GCAGATGCCGAAAGCACGCACG

- TaqMan probe: ACAGCATCTTGGTCACTTGTCTCCGGC

- NMUR2

- Forward primer: TGACCGAAGATATAGGTCCCCA

- Reverse primer: TGTTCACTAGAGAGGGCTGCTG

- TaqMan probe: TCCCATGTCAGTCATCCATGCACAACTCT

- $\beta$-Actin:

- Forward primer: GAGCTACGAGCTGCCTGACG

- Reverse primer: GTAGTTTCGTGGATGCCACAGGACT

- Taqman probe: CATCACCATTGGCAATGAGCGGTTCC

In vivo studies

All in vivo studies were conducted in accordance with the United Kingdom Animals (Scientific Procedures) Act, 1986, and conformed to GlaxoSmithKline ethics standards.

Rat NmU was administered by i.c.v. injection in all studies. Sprague-Dawley rats (Charles River, 250-300 g at the time of surgery) were implanted under anaesthesia-Domitor (medetomidine $\mathrm{HCl}, 0.4 \mathrm{mg} / \mathrm{kg}$ s.c., Pfizer, Sandwich, UK); Sublimaze (fentanyl, $0.45 \mathrm{mg} / \mathrm{kg}$ i.p., Janssen-Cilag, High Wycombe, UK)with an indwelling cannula directed towards either the left or right lateral ventricle (co-ordinates: $\pm 1.6 \mathrm{~mm}$ from midline, $0.8 \mathrm{~mm}$ caudal from bregma, $-4.1 \mathrm{~mm}$ from skull surface, with incisor bar at $-3.2 \mathrm{~mm}$ below zero, according to Paxinos and Watson 1986). Anaesthesia was reversed by Antisedan (atipamezole $\mathrm{HCl}, 2.5 \mathrm{mg}$ / $\mathrm{kg}$ s.c., Pfizer, Kent, UK) and post-operative analgesia provided by Nubain (nalbuphine $\mathrm{HCl}, 2 \mathrm{mg} / \mathrm{kg}$ s.c., Du Pont Pharmaceuticals, Letchworth Garden City, UK). Following 7 days post-operative recovery, correct cannula placement was verified by an intense drinking response to angiotensin II (100 ng i.c.v.; Simpson et al. 1978). At least 7 days elapsed before further drug testing. Rats were used in up to four separate experiments with a minimum of 7 days between each drug administration. Rats were housed singly, in a temperature-controlled environment $\left(20 \pm 1^{\circ} \mathrm{C}\right)$, under a $12-\mathrm{h} / 12-\mathrm{h}$ light/dark cycle (lights on at 0700 hours). Food and water were available ad libitum. Rats were housed in the experimental room, and all testing was conducted between 0800 hours and 1800 hours. Treatment groups were balanced for previous treatment and time of day.

Behaviour in a familiar environment

The choice of behavioural studies was based on initial pilot studies (unpublished data), in which NmU caused general arousal. Therefore, behavioural changes were measured in a familiar environment to minimise baseline activity. Following $\geq 60$-min habituation to clear Perspex observation cages $(42[L] \times 21[W] \times 20[H] \mathrm{cm})$, rats were administered $\mathrm{NmU}(3 \mu \mathrm{g}$ or $10 \mu \mathrm{g})$ or vehicle and immediately returned to the cages. Rats were videotaped for $60 \mathrm{~min}$ and behaviours [grooming (body grooming, face washing and scratch- ing), rearing and quiet (rats generally immobile and curled up)] were scored, in 15-min time bins, as both total duration(s) and number of bouts. Motor activity was scored as transits across the length of the cage. The observer was blind to treatment.

Motor activity in a familiar environment

Motor activity was measured using observation cages placed within a frame equipped with a series of infra-red beams along its length (5) and width (3) (AM1052 Activity Monitor, Benwick Electronics, Essex, UK). Following $\geqq 60$-min habituation to observation cages and the recording frame, rats were administered $\mathrm{NmU}(0.03,0.3$ or $3 \mu \mathrm{g}$ ) or vehicle and immediately returned to the recording cages. Motor activity was recorded as total activity (total beam breaks) and total transits (total ambulations across the length of the cage) in 5min time bins for $120 \mathrm{~min}$.

Pre-pulse inhibition of an acoustic startle response

Eight computer-controlled startle chambers housed in soundattenuated boxes were used for these studies (IDT, GlaxoSmithKline, Harlow). The startle chamber was constructed from clear Perspex $(19[L] \times 16[W] \times 23[H] \mathrm{cm}]$ and was equipped with a sprung metal grid floor, a loudspeaker capable of delivering a 120 $\mathrm{dB}$ tone and a light on the back wall of the chamber. The magnitude of deflection of the grid floor, caused by the startle response of the rat, was recorded by an accelerometer attached to the sprung platform. The apparatus was controlled by custom-written software (IDT, GlaxoSmithKline) run using a PC. Testing used a pulse amplitude of $110 \mathrm{~dB}$ white noise for $50 \mathrm{~ms}$, and the pre-pulse amplitude was $80 \mathrm{~dB}$ white noise for $10 \mathrm{~ms}$. Rats received five trials of pulse alone and five trials of a pre-pulse followed $60 \mathrm{~ms}$ (Inter Stimulus Interval, ISI) later by a pulse. Each of the trial types were paired in random order with an inter-trial delay of $15 \mathrm{~s}$. Background noise was $70 \mathrm{~dB}$ white noise. The data for the first pair of trials was discarded and a mean within animal figure obtained from the other four pairs of trials. Rats were habituated to the PPI procedure on four separate occasions. The animals were assigned to treatment groups based on the level of PPI and startle amplitude on the last habituation test, and balanced across startle chambers. Doses were chosen in a range that would not markedly affect motor activity (based on previous motor activity studies). On the test day, NmU $(0.1,0.3$ or $1 \mu \mathrm{g}$ i.c.v.) or vehicle was administered immediately prior to placing animals into the startle chamber and testing started 15 min later. PPI was calculated as:

$$
\begin{aligned}
& \text { PPI }= \\
& {\left[100-\left(\begin{array}{l}
\text { startle amplitude for pre }- \text { pulse }+ \\
\text { pulse } / \text { startle amplitude for pulse alone }
\end{array}\right)\right]} \\
& \times 100 .
\end{aligned}
$$

Neurochemistry and neuroendocrine hormones

Previously untreated rats were administered with $\mathrm{NmU}(0.03,0.3$ and $3 \mu \mathrm{g}$ ) or vehicle and, $20 \mathrm{~min}$ later, were killed by rapid decapitation. The dose range and sampling times were based on peak motor activity and grooming times from behavioural studies.

\section{Neuroendocrine hormones}

Trunk blood was collected into pre-chilled tubes containing EDTA and centrifuged at $1750 \mathrm{~g}\left(4^{\circ} \mathrm{C}\right)$ for $15 \mathrm{~min}$ to harvest plasma which was then stored at $-70^{\circ} \mathrm{C}$ for radioimmunoassay of prolactin, thyroid stimulating hormone (TSH), luteinising hormone (LH) (Amersham 
Life Science Ltd, UK) and corticosterone (Immunodiagnostic Systems Limited, UK).

\section{Neurochemistry}

Sample preparation Brains were removed, frozen and stored at $-80^{\circ} \mathrm{C}$ until assay. Tissue samples were dissected from the dorsal striatum, nucleus accumbens, hippocampus, hypothalamus and frontal cortex (both left and right hemispheres) and snap frozen in $1.5 \mathrm{ml}$ Eppendorf sample tubes on cardice. The frozen samples were then transferred into a pre-weighed 1.5-ml Eppendorf sample tube. A volume of $10 \mu \mathrm{l}$ homogenising buffer $(0.1 \% \quad \mathrm{w} / \mathrm{v} \quad \mathrm{Na}$ Metabisulphite, $0.01 \% \mathrm{w} / \mathrm{v}$ EDTA, $0.1 \% \mathrm{w} / \mathrm{v}$ L-cysteine, $0.4 \mathrm{M}$ perchloric acid) per milligram of tissue was then added to each sample region and homogenised using an electric homogeniser (Ultra Turrax T25, Janke and Kunkel, Germany). A volume of the resultant slurry was put into a 1.5-ml Eppendorf and spun on a centrifuge (Labofuge 400R, Heraeus Instruments, Germany) at $9500 \mathrm{~g}, 4^{\circ} \mathrm{C}$ for $10 \mathrm{~min}$. After centrifugation, $20 \mu \mathrm{l}$ of the clear supernatant layers were put into a limited volume glass vial $(0.2 \mathrm{ml}$ borate silica vials, Chromacol, UK). Vials were then placed into a cooled autosampler tray (832 Temperature regulator, Gilson, France) at $4^{\circ} \mathrm{C}$ and run on the high-performance liquid chromatography (HPLC) system.

Chromatographic conditions A solvent delivery pump (PU-980, Jasco, Japan) was used in conjunction with an electrochemical amperometric detector (Decade, Antec-Leyden, Netherlands) fitted with a 3-mm glassy carbon electrode with a working electrode set at $+800 \mathrm{mV}$ versus $\mathrm{Ag} / \mathrm{AgCl}$ (VT-03, Antec-Leyden, Netherlands). The signal was then passed through a low-pass in-line noise killer (Antec-Leyden, Netherlands) set at 26-s peak width before the data was captured using Waters Millennium ${ }^{32}$. An autosampler (234 Autosampler, Gilson, France) fitted with a six port rotary valve (Model 7125, Rheodyne, Berkley, CA, USA) with a 20- $\mu$ l injection loop was used for a $5 \mu$ central loop fill injection of brain tissue samples. Chromatographic separations were performed using a Waters Symmetry $\left(\mathrm{C}_{18} 3.5 \mu \mathrm{m}, 4.6 \times 75 \mathrm{~mm}\right)$ column fitted with a $20-\mathrm{mm} \quad \mathrm{C}_{18}$ Waters Sentry guard column. The mobile phase consisted of $0.07 \mathrm{M} \mathrm{KH}_{2} \mathrm{PO}_{4}$ (Fisher, UK, HPLC for Electrochemical Detection Grade), $1 \mathrm{mM}$ octane sulphonic acid (Fisher, UK, HPLC for Electrochemical Detection Grade) and $0.1 \mathrm{mM} \mathrm{Na}$ EDTA (Fisher, UK, 0.1 M solution, HPLC for Electrochemical Detection Grade) made up in $10 \% \mathrm{MeOH}$ (Methanol 205, Super Purity, Romil, Cambridge, UK), 0.5\% propan-2-ol (Super Purity, Romil, Cambridge, UK); the $\mathrm{pH}$ was adjusted to 2.85 with orthophosphoric acid ( $85 \%$, Fisher, UK HPLC grade). The mobile phase was then filtered through a $0.22-\mu \mathrm{m}$ filter (Millipore, Bedford, MA, USA), degassed on line (DEG-103, Kontron, Japan) and delivered at a rate of $1.50 \mathrm{ml} / \mathrm{min}$ at a temperature of $30^{\circ} \mathrm{C}$. Samples were compared against a calibration curve generated by a mixed standard of $1,3,10,30,50$ and $100 \mathrm{ng} / \mathrm{ml}$ of 3,4-dihydroxyphenylacetic acid (DOPAC), dopamine $\mathrm{HCl}$ (DA), 5-hydroxyindole-3acetic acid (5-HIAA), homovanillic acid (HVA), 3-methoxytyramine HCL (3-MT), and 5-hydroxytryptamine creatine sulphate (5-HT) (all components from Sigma, St. Louis, USA). Components in the samples were then identified by retention time and quantified using the calibration curve with a final adjustment for the dilution by homogenising buffer and taking into account the presence of either hydrochloride or the creatine sulphate complex. The levels of substrates in each brain sample were expressed as nanogram per milligram of tissue. Turnover rates were assessed by calculating the following ratios: DOPAC/DA, HVA/DA, and 5-HIAA/5-HT.

\section{Fos-like immunohistochemistry}

Rats previously used in another behavioural study (response to i.c.v. orexin-B) were allowed 21 days recovery with regular handling, and treatment groups were randomised according to previous injection.
Rats were injected with vehicle or $\mathrm{NmU}(10 \mu \mathrm{g}$ i.c.v.) and returned to their home cage. Two hours post-injection, animals were anaesthetised with sodium pentobarbitone $\left(200 \mathrm{mg} \mathrm{kg}^{-1}\right.$, i.p. $)$ and intracardially perfused with heparinised saline followed by $4 \%(\mathrm{w} / \mathrm{v})$ paraformaldehyde (PFA, $200 \mathrm{ml}$ ) in $0.1 \mathrm{M}$ phosphate buffer. Fos immunohistochemistry was carried out according to the methods of Leslie et al. (1993). In summary, brains were removed and postfixed for 2 days in $4 \%$ PFA $\left(4^{\circ} \mathrm{C}\right)$. Coronal sections $(50 \mu \mathrm{m})$ were cut on a cryostat and each brain section individually placed into immunobuffer $\left(120 \mathrm{mM} \mathrm{NaCl}, 5 \mathrm{mM} \mathrm{KCl}, 9 \mathrm{mM} \mathrm{Na} 2 \mathrm{HPO}_{4}, 15 \mathrm{mM}\right.$ $\mathrm{NaH}_{2} \mathrm{PO}_{4}, 1 \mathrm{mM}$ merthiolate containing $0.3 \%$ [v/v] Triton X-100). Endogenous peroxidase activity was removed with hydrogen peroxide $\left(\mathrm{H}_{2} \mathrm{O}_{2}, 30 \mathrm{~min}, 0.03 \%\right.$ [v/v] in immunobuffer) prior to sequential incubation in $2 \%(\mathrm{v} / \mathrm{v})$ rabbit serum in immunobuffer (blocking buffer, $24 \mathrm{~h}$ ), followed by affinity-purified polyclonal sheep antiserum raised to the c-fos protein (1:2000 in blocking buffer, $60 \mathrm{~h}$; Genosys Biochemicals, UK, Cat. No. OA-11-824), and then biotinylated secondary rabbit anti-sheep antibody (1:200 in blocking buffer, $24 \mathrm{~h}$ ). Sections were incubated in avidin/biotin/ horseradish peroxidase conjugate $(3 \mathrm{~h})$, followed by incubation in 3 , $3^{\prime}$ diaminobenzidine $(\mathrm{DAB}, 0.3 \%[\mathrm{w} / \mathrm{v}], 10 \mathrm{~min}$ in $0.1 \mathrm{M}$ phosphate buffer [pH 7.4]). To reveal sites of Fos-like immunoreactivity (FLI; black-brown nuclear staining), $\mathrm{H}_{2} \mathrm{O}_{2}[20 \mu \mathrm{l}, 0.1 \%(\mathrm{v} / \mathrm{v})]$ solution was added to the DAB solution and washed off with Tris- $\mathrm{HCl}$ $(50 \mathrm{mM}, \mathrm{pH} 7.4)$ once sections had turned a beige-brown colour. All sections were further washed $(\times 2)$ in Tris- $\mathrm{HCl}$ to ensure the removal of all DAB solution, mounted onto glass microscope slides and allowed to dry overnight. In order to observe FLI under a light microscope, sections were dehydrated in absolute alcohol and cleared using Citroclear (xylene substitute), and cover-slipped with DPX mounting medium. Sections were examined by bright-field microscopy and cells that exhibited FLI in pre-selected brain regions (nucleus accumbens, frontal cortex, paraventricular thalamus, hippocampus, central amygdala and paraventricular hypothalamus) were counted by an independent observer blind to treatment group. Nuclei were counted in a $400 \times 400-\mu \mathrm{m}$ box. Where the box extended beyond the chosen anatomical region, counting was limited to the boundary of that region.

\section{Preparation and administration of Neuromedin-U}

Rat NmU was purchased as an acetate salt from Bachem (UK) Ltd. The peptide was dissolved in sterile $0.9 \%$ saline solution and doses were corrected for salt content. The $\mathrm{pH}$ of the peptide solution was adjusted to approximately 7 , using $0.5 \mathrm{M} \mathrm{NaOH}$ solution. Aliquots of the highest concentration of $10 \mu \mathrm{g}(3.8 \mathrm{nmol})$ were snap frozen at $-80^{\circ} \mathrm{C}$ prior to storage at $-20^{\circ} \mathrm{C}$. On experimental days, individual aliquots were stored on ice and discarded at the end of each day. In all studies, $\mathrm{NmU}$ or vehicle were injected i.c.v. in a volume of $5 \mu \mathrm{l}$ over $60 \mathrm{~s}$ at a constant rate. The injection needle (extending $1 \mathrm{~mm}$ from the end of the guide cannula) was left in place for a further $90 \mathrm{~s}$ to allow for complete diffusion of the peptide.

\section{Data analysis}

Data for observed behaviours were analysed using Kruskall-Wallis one-way analysis of variance (ANOVA) by ranks followed by Mann-Whitney $U$-tests where appropriate. Total motor activity, \% PPI, startle amplitude and endocrine hormones were analysed using one-way ANOVA followed by Dunnett's $t$-test post-hoc analysis. Data for activity $\times$ time and transits $\times$ time were analysed using twoway ANOVA followed by least significant difference post-hoc analysis at individual time points. Data were transformed to correct for heterogeneity of variance when appropriate. Data for steady-state levels of transmitters were analysed using a $4 \times 5 \times 6$ ANOVA with a main factor of dose $(0,0.03,0.3,3 \mu \mathrm{g})$, and repeated-measurements factors of brain region (dorsal striatum, nucleus accumbens, hippocampus, hypothalamus and frontal cortex) and neurochemical index (DA, DOPAC, HVA, 3-MT, 5-HT, 5-HIAA). Turnover rates 
were analysed using a $4 \times 5 \times 4$ ANOVA with a main factor of dose $(0$, $0.03,0.3,3 \mu \mathrm{g}$ ), and repeated-measurements factors of brain region (dorsal striatum, nucleus accumbens, hippocampus, hypothalamus and frontal cortex) and turnover ratio (DOPAC/DA, HVA/DA, DOPAC/HVA, 5-HIAA/5-HT). Differences between individual means were analysed using the post-hoc Fisher's Protected test. For immunohistochemistry studies, counts for numbers of immunoreactive nuclei in each region were assessed using one-way ANOVA followed by Duncan's New Multiple Range post-hoc analysis. All statistical analyses used Statistica (Statsoft, Ca, USA). In all cases $P<0.05$ was taken as the level of significance.

\section{Results}

Binding affinity and functional potency of $\mathrm{NmU}$ at NMU1R and NMU2R

We studied the binding affinity and functional potency of rat NmU at both human NMU1R and human NMU2R when transiently expressed in HEK293 cells. NmU was able to displace $\left[{ }^{125} \mathrm{I}\right]$-pNmU25 with equal potency from both NMU1R $\left[K_{\mathrm{I}}=0.11 \pm 0.02 \mathrm{nM}(n=4)\right]$ and NMU2R $\left[K_{\mathrm{I}}=0.21 \pm 0.05 \mathrm{nM}(n=5)\right]$ (Fig. 1). In functional calcium mobilization assays performed on a FLIPR, NmU was a full agonist at both NMU1R and NMU2R with mean $\mathrm{EC}_{50}$ values of $1.25 \pm 0.05 \mathrm{nM}$ for NMU1R and $1.10 \pm 0.20 \mathrm{nM}$ for NMU2R ( $n=4)$ (Fig. 2). Thus, NmU is equally active at both NMU1R and NMU2R.

\section{Quantitative RT-PCR analysis}

Expression of NMUR1 and NMUR2 mRNA in human tissues is shown in Fig. 3a. NMU1R mRNA was expressed at low levels in all CNS tissues assessed. In peripheral tissues, expression was highest in adipose tissue and moderate in lung, intestine, spleen and lymphocytes. NMU2R mRNA was found in all brain CNS tissues assessed with highest levels in the hypothalamus, medulla oblongata, substantia nigra and thalamus. In periphery,

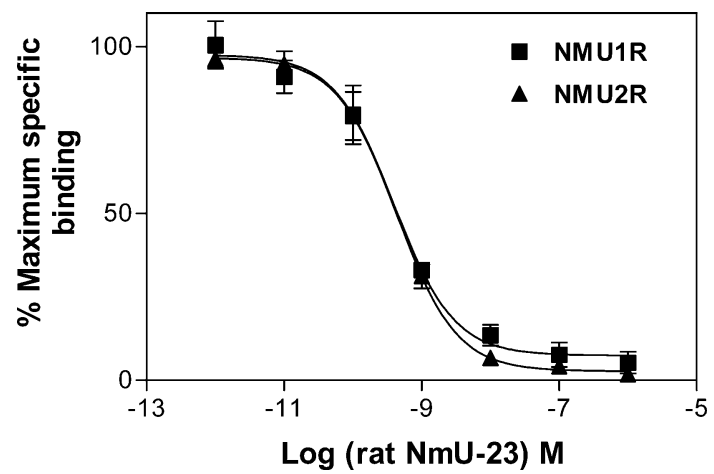

Fig. 1 Competition binding curves for rat neuromedin-U (NmU) against $\left[{ }^{125} \mathrm{I}\right]$ porcine NmU-25 binding to membranes isolated from HEK293 cells transiently transfected with human NMU1R (filled square) and NMU2R (filled triangle). Data are means of duplicate determinations from one representative experiment. Mean $K_{\mathrm{I}}$ values were $0.11 \pm 0.02 \mathrm{nM}(n=4)$ and $0.21 \pm 0.05 \mathrm{nM}(n=5)$ for NMU1R and NMU2R, respectively

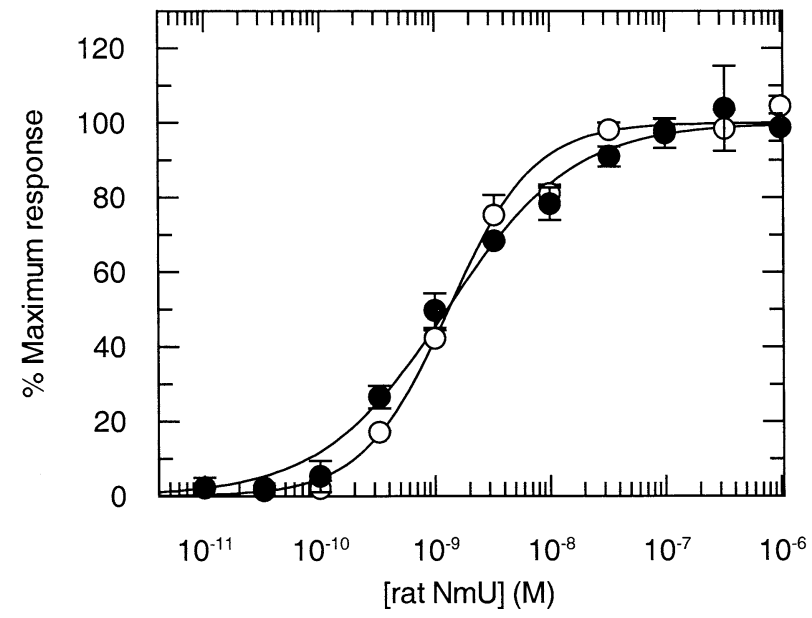

Fig. 2 Concentration-dependent stimulation of $\mathrm{Ca}^{2+}$ mobilization by rat neuromedin-U (NmU) in HEK293 cells transiently expressing NMU1R or NMU2R. Data is expressed as a percentage of the maximal response seen for each receptor. Mean $\mathrm{EC}_{50}$ values were $1.25 \pm 0.05 \mathrm{nM}$ for NMU1R and $1.10 \pm 0.20 \mathrm{nM}$ for NMU2R $(n=4)$

relatively low expression of NMU2R mRNA was detected in the heart, lung, kidney and stomach.

Expression of NMU1R and NMU2R mRNA in rat tissues is shown in Fig. 3b. NMU1R mRNA could not be detected in any CNS areas assessed, with the exception of very low levels of expression in the amygdala. In peripheral tissues, expression of NMU1R was found in lung, small intestine, stomach and testis, with the highest levels detected in the spleen. NMU2R mRNA expression was detected at highest levels in CNS tissues, with the highest expression in the medulla oblongata. Moderate levels of expression were found in the hypothalamus, spinal cord, striatum and whole brain tissue. Low levels of expression were found in all other CNS tissues, including all cortical areas; however, no expression was detected in the hippocampus. In peripheral tissues, highest levels of NMU2R receptor expression were detected in the ovary with lower levels of expression also found in the lung, stomach and testis.

Behaviour in a familiar environment

Centrally administered $\mathrm{NmU}$ induced a behavioural syndrome characterised by an intense grooming response. $\mathrm{NmU}$ increased the time spent face washing $[H(2, N=18)$ $=8.67, P<0.05 ;$ Fig. $4 \mathrm{a}]$, time spent scratching $[H(2, N=18)$

Fig. 3 TaqMan quantitative reverse-transcription polymerase chain reaction (RT-PCR) analysis of NMU1R and NMU2R mRNA levels. In human tissues (a) the cDNA from the reverse transcription of 1 ng poly A + RNA from multiple tissues for four different nondiseased individuals was assessed for its NMUR and housekeeper genes ( $\beta$-actin shown for reference) using TaqMan PCR. Data are presented as the mean $( \pm$ SEM) of four individuals' mRNA levels for each tissue. (Intestine is an equal pool of one individual's small and another individual's large intestine). In rat tissues (b) data is for copies of mRNA per nanogram total RNA. Data are presented as mean $( \pm$ SEM) of four independent RT-PCRs using total RNA pooled from $6-16$ rats 

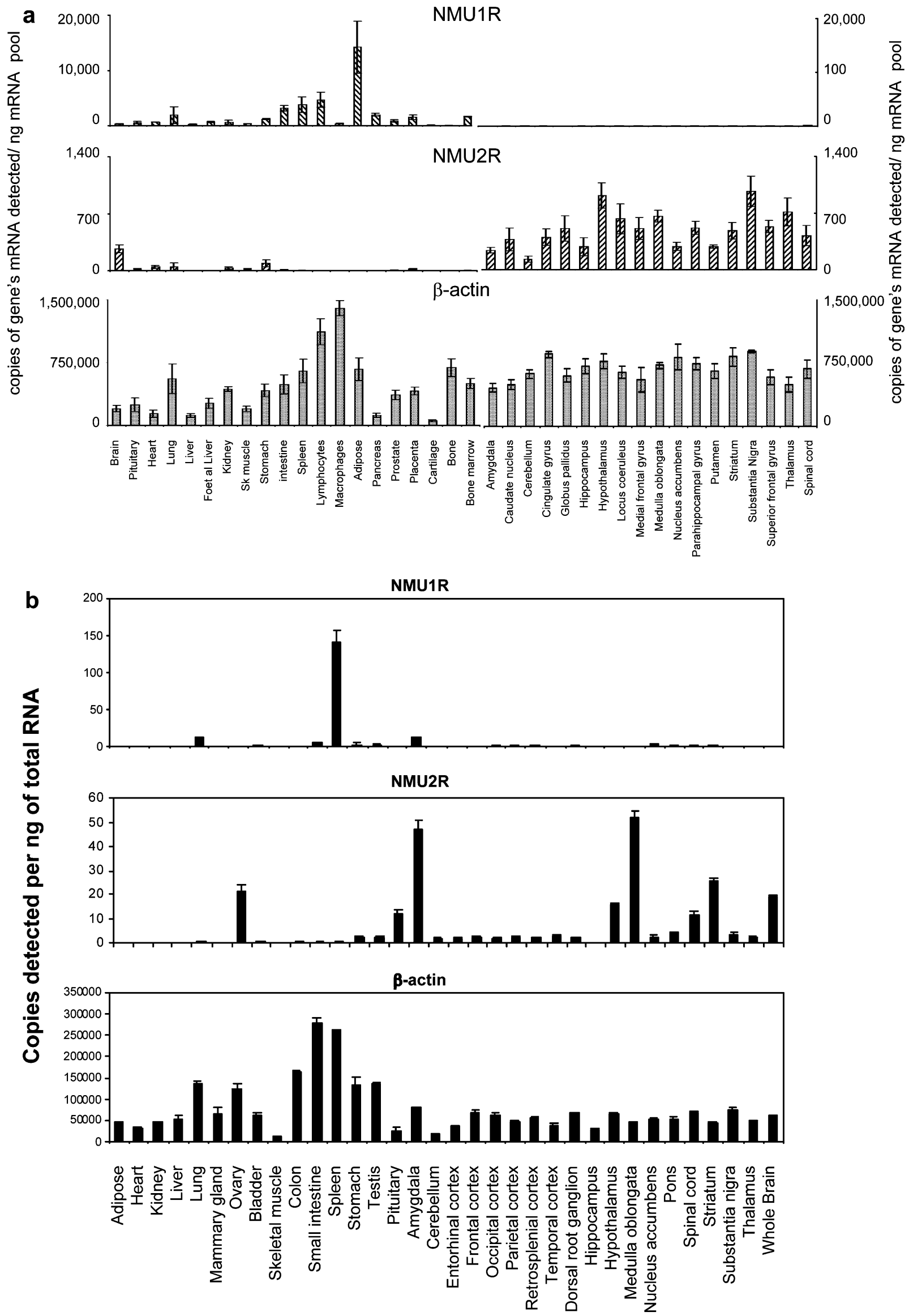
$=11.84, P<0.05$; Fig. 4b] and time spent body grooming $[H(2, N=18)=8.47, P<0.05$; Fig. $4 \mathrm{c}]$, at $3 \mu \mathrm{g}$ and $10 \mu \mathrm{g}$ $(P<0.05)$. The reduction in time spent quiet was pronounced $[H(2, N=18)=10.75, P<0.05$; Fig. 4d] at $3 \mu \mathrm{g}$ and $10 \mu \mathrm{g}(P<0.05)$. Time spent rearing was not affected (data not shown). NmU also increased bouts of face washing $[H(2, N=18)=9.6, \quad P<0.05]$, bouts of scratching $[H(2, N=18)=12.45, P<0.01]$ and bouts of body grooming $[H(2, N=18)=8.67, P<0.05]$ at $3 \mu \mathrm{g}$ and $10 \mu \mathrm{g}(P<0.05)$ (bouts data not shown). Bouts of rearing and quiet behaviour were not affected (data not shown). $\mathrm{NmU}$ did not affect total number of cage transits (data not shown).

Motor activity in a familiar environment

NmU-stimulated motor activity (Fig. 5). Total activity was increased $\left(F_{3,41}=10.06, P<0.05\right.$, Fig. 5a) at $0.3 \mu \mathrm{g}$ and $3 \mu \mathrm{g} \quad(P<0.05)$. NmU did not affect total transits (ambulations across the length of the cage) (Fig. 5c,d), suggesting that the observed increase in total activity does not represent horizontal locomotor activity. The stimulatory effects of $\mathrm{NmU}$ on activity changed significantly over
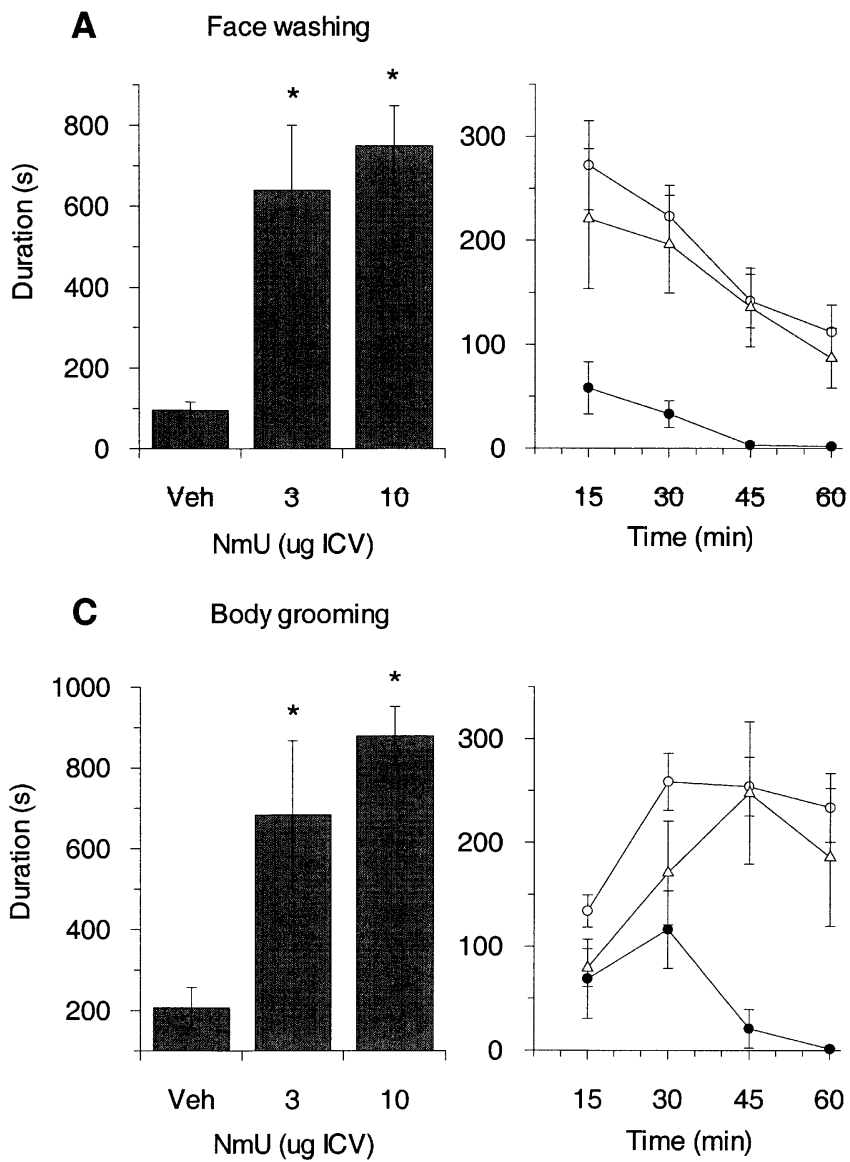

Fig. 4a-d Effects of neuromedin-U (NmU) on observed behaviour $(n=6)$. Behaviours were scored in 15 -min time bins for 60 min postdose. For individual behaviours, total time spent is shown in the left panel and time spent during each 15-min time bin is shown in the the 120 -min recording period $\left(F_{33,451}=4.49, \quad P<0.05\right.$, Fig. 5b) with a return to baseline levels of activity after $110 \mathrm{~min}$. At $0.3 \mu \mathrm{g}$, activity was elevated above vehicle levels between $20 \mathrm{~min}$ and $70 \mathrm{~min}$ post-injection. At the highest dose $(3 \mu \mathrm{g})$, activity was elevated significantly for between $10 \mathrm{~min}$ and $100 \mathrm{~min}$ post-injection $(P<0.05$ at each time interval).

Pre-pulse inhibition of an acoustic startle response

$\mathrm{NmU}$ did not affect PPI (for example, vehicle $=59.6 \pm 5.4$ $1 \mu \mathrm{g}=55.6 \pm 6.5 \%$ PPI, data not shown) or startle amplitude (for example, vehicle $=1788 \pm 225 ; 1 \mu \mathrm{g}=1973 \pm 297$ arbitrary units, data not shown).

Neurochemistry and neuroendocrine markers

\section{Neuroendocrine hormones}

NmU caused a dose-related reduction in plasma prolactin levels, which was significant at $3 \mu \mathrm{g}(P<0.05$; Fig. 6).
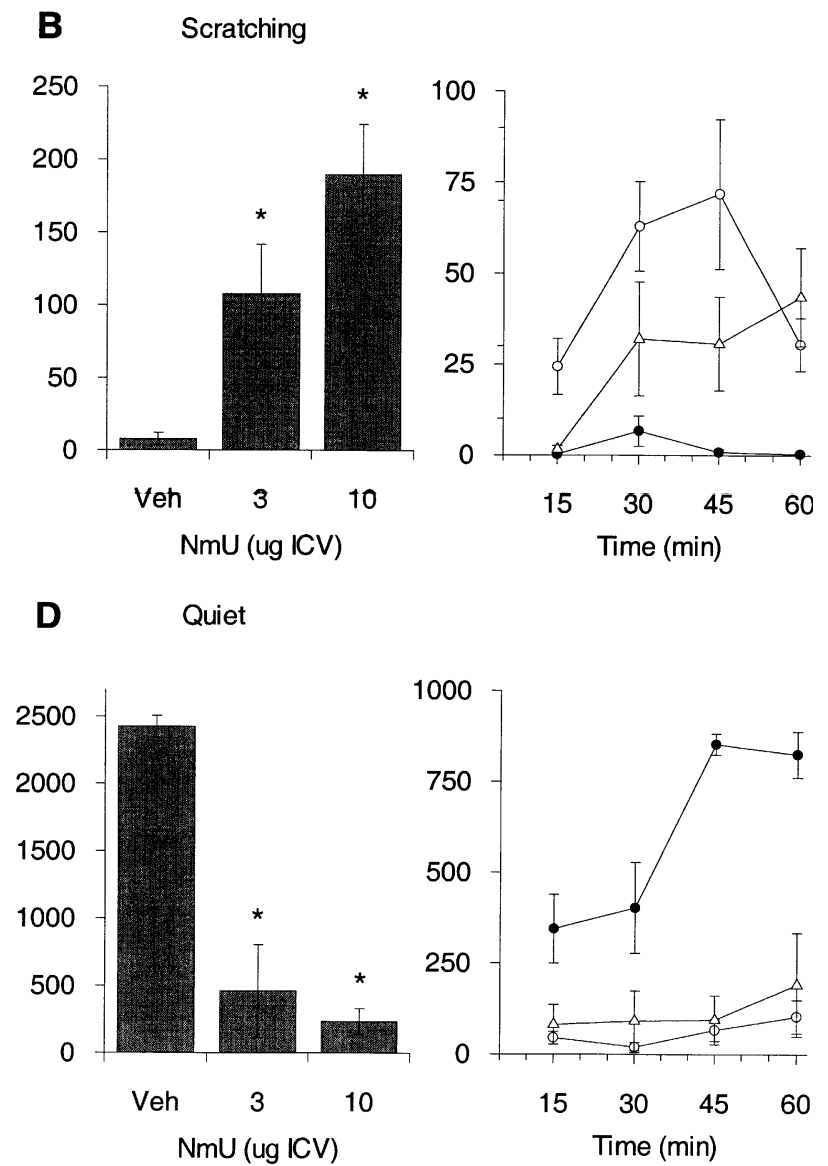

right panel. a Data for time spent face washing (s), b time spent scratching (s), c time spent body grooming (s) and $\mathbf{d}$ time spent quiet (s) are shown as the means $( \pm$ SEM). Significant differences from vehicle are shown by $* P<0.05$ 
A
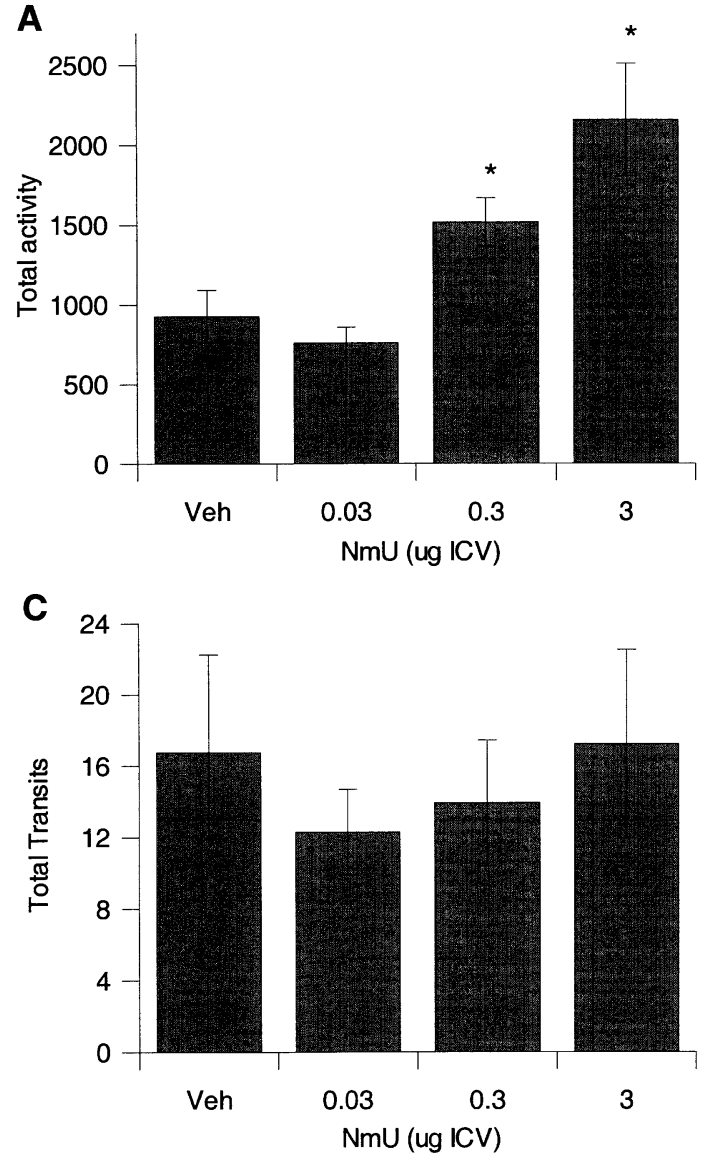

Fig. 5a-d Effects of neuromedin-U (NmU) on motor activity in a familiar environment $(n=10-12)$. Motor activity was recorded in 5min time bins for 120 min post-dose. Data for total activity (a) and
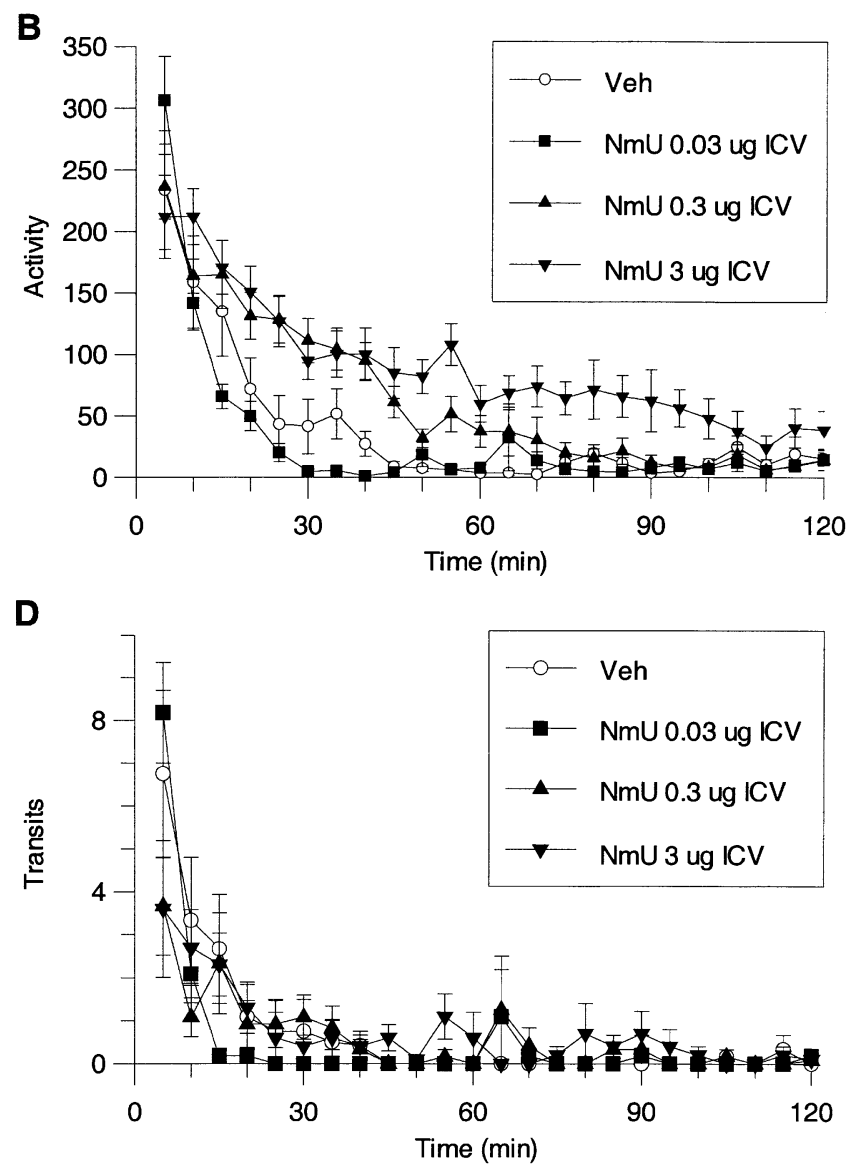

total transits (c), and for total activity (b) and total transits (d) over time are shown as the means $( \pm$ SEM). Significant differences from vehicle are shown by $* P<0.05$
Table 1 Effects of neuromedin$\mathrm{U}(\mathrm{NmU})$ on serotonin $(5-\mathrm{HT})$ neurotransmission in rat brain extracts. Data are expressed as means $( \pm$ SEM). Significant differences from vehicle are shown by $* P<0.05$

\begin{tabular}{llll}
\hline Brain region & NmU $(\mu$ g i.c.v. $)$ & {$[5-\mathrm{HT}]$} & {$[5-\mathrm{HIAA}] /[5-\mathrm{HT}]$} \\
\hline Frontal cortex & Vehicle & $410.42 \pm 15.76$ & $0.496 \pm 0.023$ \\
& 0.03 & $428.37 \pm 09.00$ & $0.405 \pm 0.021$ \\
Hippocampus & 3.3 & $411.97 \pm 23.02$ & $0.431 \pm 0.028$ \\
& Vehicle & $471.94 \pm 18.40^{*}$ & $0.481 \pm 0.047$ \\
& 0.03 & $263.76 \pm 16.48$ & $1.007 \pm 0.064$ \\
Hypothalamus & 0.3 & $270.03 \pm 11.78$ & $0.907 \pm 0.072$ \\
& 3 & $247.77 \pm 11.09$ & $0.810 \pm 0.048^{*}$ \\
& Vehicle & $293.88 \pm 24.21$ & $0.824 \pm 0.036$ \\
Nucleus accumbens & 0.03 & $505.61 \pm 22.33$ & $0.523 \pm 0.025$ \\
& 0.3 & $566.03 \pm 11.10$ & $0.489 \pm 0.021$ \\
& 3 & $598.83 \pm 19.42^{*}$ & $0.463 \pm 0.021$ \\
& Vehicle & $571.36 \pm 27.35^{*}$ & $0.446 \pm 0.016^{*}$ \\
Striatum & 0.03 & $466.26 \pm 26.56$ & $0.733 \pm 0.045$ \\
& 0.3 & $463.89 \pm 33.59$ & $0.743 \pm 0.061$ \\
& 3 & $406.05 \pm 28.34$ & $0.752 \pm 0.028$ \\
& Vehicle & $456.16 \pm 26.47$ & $0.732 \pm 0.030$ \\
& 0.03 & $273.93 \pm 17.91$ & $1.180 \pm 0.112$ \\
& 0.3 & $270.78 \pm 08.62$ & $1.103 \pm 0.044$ \\
& 3 & $269.88 \pm 13.76$ & $1.117 \pm 0.061$ \\
& & $307.47 \pm 19.41$ & $1.065 \pm 0.230$ \\
\hline
\end{tabular}


Fig. 6a-d Effects of neuromedin- $\mathrm{U}(\mathrm{NmU})$ on plasma endocrine hormones. Trunk blood samples were collected $20 \mathrm{~min}$ post-dose for radioimmunoassay. Levels of corticosterone (ng/ml) (a), LH (ng/ml) (b), prolactin $(\mathrm{ng} / \mathrm{ml})(\mathbf{c})$ and $\mathrm{TSH}$ $(\mathrm{ng} / \mathrm{ml})(\mathbf{d})$ are shown as the means $( \pm$ SEM). Significant differences from vehicle are shown by $* P<0.05$
A

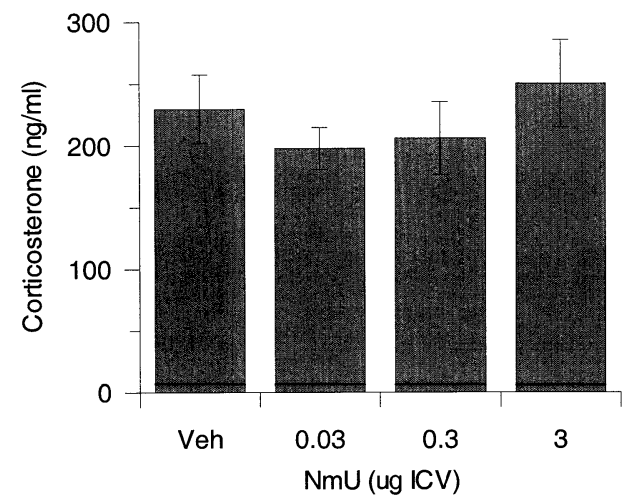

C

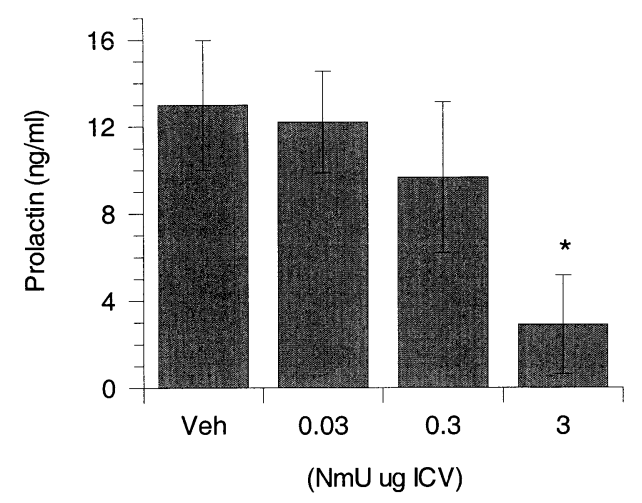

B

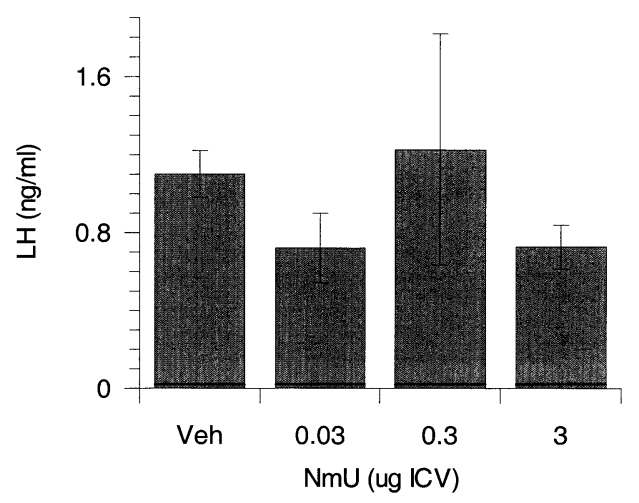

D

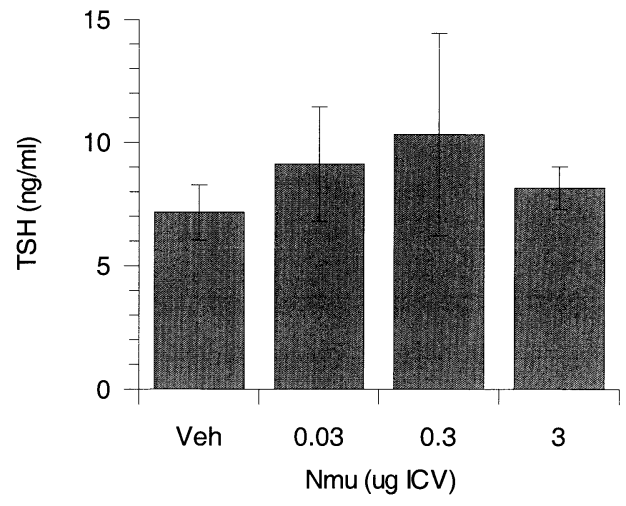

Plasma levels of corticosterone, LH or TSH were not affected.

\section{Neurochemistry}

NmU significantly affected 5-HT neurotransmission in the frontal cortex and hypothalamus (Table 1). In the frontal cortex, the overall ANOVA revealed a main effect of dose $\left(F_{3,24}=3.4 ; \quad P<0.05\right)$ and a significant neurochemical index $\times$ dose interaction $\left(F_{12,96}=1.8 ; P=0.05\right)$. The posthoc Fisher's test confirmed that NmU $(3 \mu \mathrm{g})$ produced a significant increase in steady-state levels of 5-HT $(P<0.05)$. In the hypothalamus, ANOVA yielded a significant neurochemical index $\times$ dose interaction $\left(F_{12,96}=1.9\right.$; $P<0.05)$. NmU $(0.3 \mu \mathrm{g}$ and $3 \mu \mathrm{g})$ were shown to increase levels of 5-HT significantly $(P<0.01$ and $P<0.05$, respectively). NmU (3 $\mu \mathrm{g})$ also decreased significantly the turnover of 5-HT, as expressed by the 5-HIAA/5-HT ratio $(P<0.05)$. NmU did not affect levels of DA or the ratio of DA to its metabolites in any brain region tested (data not shown).

\section{Fos-like immunohistochemistry}

$\mathrm{NmU}(10 \mu \mathrm{g})$ markedly increased the number of Fos-like immunoreactive cell bodies in the nucleus accumbens, frontal cortex and central amygdala compared with vehicle $(P<0.05$; Figs 7,8$)$. NmU did not alter levels of FLI in the paraventricular thalamus, hippocampus or paraventricular hypothalamus.

\section{Discussion}

In agreement with previous data (Raddatz et al. 2000; Howard et al. 2000), the results of in vitro functional and

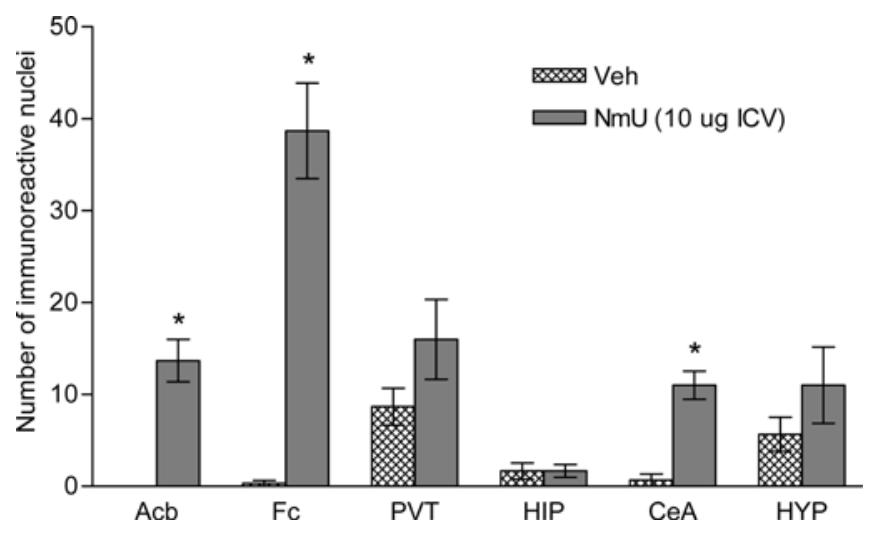

Fig. 7 Numbers of Fos-like immunoreactive nuclei were determined in brains perfused $2 \mathrm{~h}$ after i.c.v. administration of vehicle or neuromedin-U (NmU; $10 \mu \mathrm{g})$. Fos-like immunoreactivity (FLI) was counted in a $400 \times 400-\mu \mathrm{m}$ grid (by an observer blind to treatment group) in the nucleus accumbens (Acb), frontal cortex (Fc), paraventricular thalamus (PVT), hippocampus (HIP), central amygdala (CeA) and paraventricular hypothalamus (HYP). Significant increases in FLI were evident in the Acb, Fc and CeA. ${ }^{*} P<0.05$ after significant one-way ANOVA, $n=3$ per group 
Fig. 8 Photomicrograph of indicative Fos-like immunoreactivity (FLI) in the central amygdala $(\mathrm{CeA})$ of a neuromedin-U (NmU; $10 \mu$ g i.c.v.)treated (A) or vehicle-treated (B) rat, and in the frontal cortex (Fc) of a NmU- (10 $\mu$ g i.c.v.) (C) or vehicle- (D) -treated rat. Intense FLI (arrow) was evident only in the brains of animals administered NmU. Bar $200 \mu \mathrm{m}$
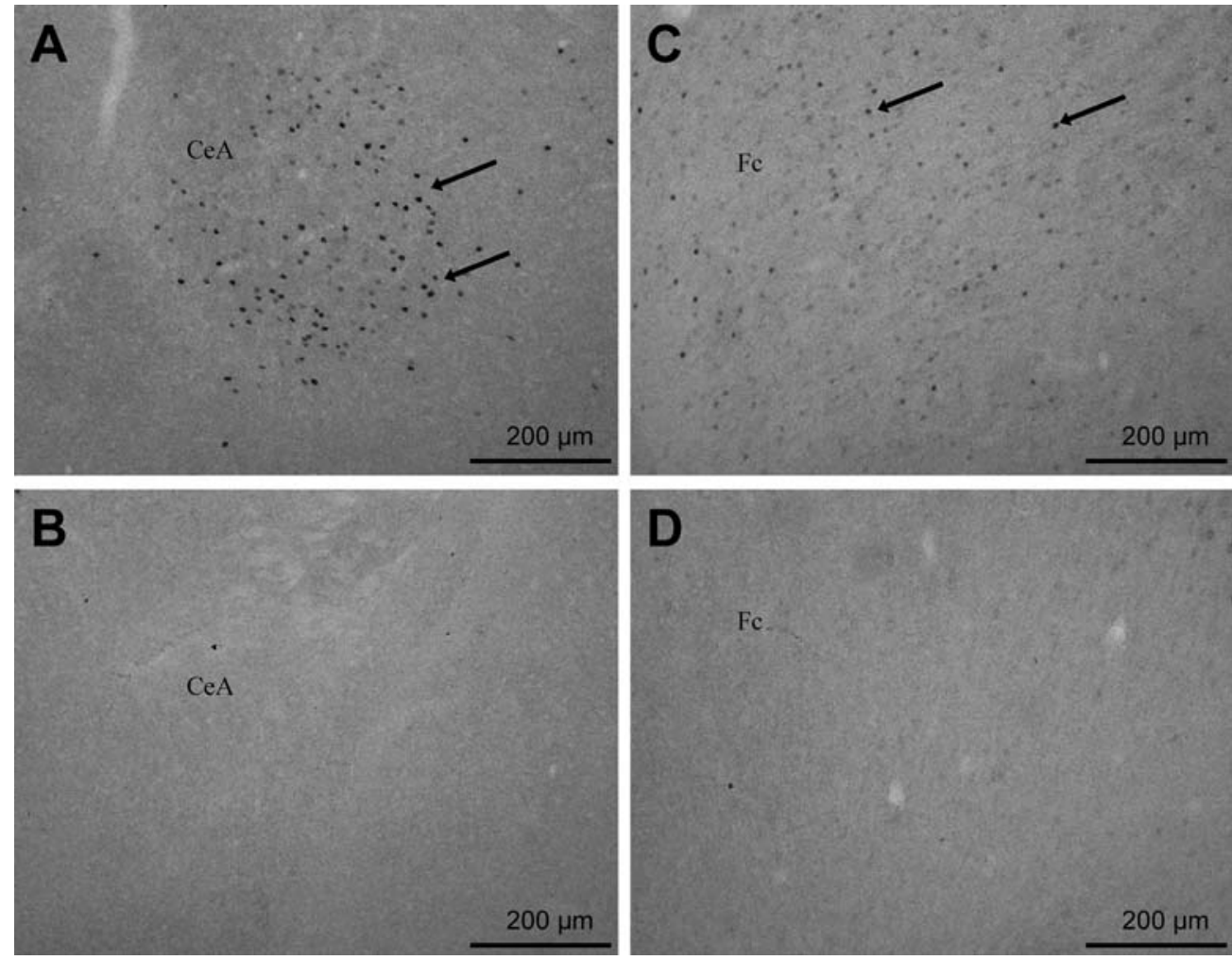

binding assays showed that rat $\mathrm{NmU}$ is a potent agonist at both NMU1R and NMU2R. Given the CNS localisation of these subtypes, these data confirm that the in vivo effects of NmU described here could be mediated by either of these receptors. Here, we provide the first concurrent description of NMU1R and NMU2R in both rat and human tissues, extend the description of behavioural activation following $\mathrm{NmU}$ and provide the first description of NmU affecting 5-HT neurochemistry and plasma prolactin levels. Further, we showed discrete FLI in the frontal cortex, nucleus accumbens and central amygdala.

To address discrepancies in previous reports of NMU1R and NMU2R distribution, RT-PCR was used to measure NMU1R and NMU2R mRNA in rat and human tissues. Expression of a housekeeping gene, $\beta$-actin, was used to control for discrepancies in RNA quality between tissue samples. In both rats and humans, NMU1R mRNA was detected in peripheral tissues, with highest expression in the gastrointestinal tract including the stomach, intestine and spleen. In agreement with Raddatz et al. (2000), very low levels of NMU1R mRNA were detected in human brain. With the exception of the amygdala, NMU1R mRNA was undetectable in rat brain. However, NMU1R mRNA was expressed in the rat amygdala, implying that a role for NMU1R in the brain cannot be ruled out. This description of NMU1R in the rat brain contrasts with Fujii et al. (2000) and Howard et al. (2000), who could find no evidence of NMU1R mRNA expression in any brain region tested, using in situ hybridisation. Such discrepancies may partly be explained by differences in the methodologies and sensitivities of the detection system. Overall, the distribution of NMU1R reported here is in broad agreement with previous reports of NMU1R distribution in humans (Raddatz et al. 2000; Hedrick et al. 2000; Howard et al. 2000) and rats (Howard et al. 2000; Fujii et al. 2000), and is consistent with roles for NMU1R and NMU2R in peripheral smooth muscle contraction and in gastrointestinal function (Szekeres et al. 2000). Future studies will use selective radiolabelled ligands, or antibodies to the receptor, to map the localisation of receptor protein.

Expression of NMU2R mRNA was relatively high in the CNS of rats and humans. Whilst these data are in general agreement with other recent reports of NMU2R mRNA distribution shown using RT-PCR (Hosoya et al. 2000; Raddatz et al. 2000), Northern analysis (Howard et al. 2000; Shan et al. 2000) and in situ hybridisation (Howard et al. 2000), here we show a more diverse brain expression of NMU2R mRNA. There were higher CNS levels of expression of NMU2R in all 18 human regions tested. Expression in rats was relatively high in the medulla oblongata, pons, spinal cord, striatum, substantia nigra and whole brain tissue. The presence of NMU2R mRNA in the nucleus accumbens, striatum and substantia nigra has not been previously described. Higher levels of NMU2R mRNA were found in the hypothalamus of both species, confirming previous reports by Raddatz et al. (2000) and Hosoya et al. (2000) and, importantly, Howard et al. (2000) who showed mRNA expression specifically in the hypothalamic paraventricular nucleus (PVN) and in the lining of the third ventricle of the hypothalamus. The reported effects of centrally administered $\mathrm{NmU}$ on food intake, energy expenditure and stress regulation (Howard et al. 2000; Nakazato et al. 2000; Wren et al. 2002) are 
consistent with the hypothalamic localisation of both NMU2R and NmU. However, the overall brain distribution of NMU2R and, to a lesser extent, NMU1R suggests that the central functions of $\mathrm{NmU}$ and its receptors are more widespread. To reveal further central roles for $\mathrm{NmU}$, we characterised the response to i.c.v.-administered $\mathrm{NmU}$ by measuring various behavioural, neurochemical and neuroendocrine end points.

A detailed examination of the behavioural outcomes following $\mathrm{NmU}$ (up to $10 \mu \mathrm{g}$ ) revealed that $\mathrm{NmU}$ caused an intense behavioural syndrome in rats. As previously reported (Kojima et al. 2000; Hanada et al. 2001; Wren et al. 2002), NmU (3-10 $\mu \mathrm{g})$ caused a marked increase in grooming and grooming-related behaviours (face washing and scratching), and reduced time spent quiet. $\mathrm{NmU}$ (up to $3 \mu \mathrm{g}$ ) also increased motor activity in a familiar environment in a dose-dependent manner. In agreement with Nakazato et al. (2000), the motor activation was prolonged with elevation in levels of activity for up to $100 \mathrm{~min}$. This contrasts with findings by Howard et al. (2000) who reported a "transient" increase in motor activity following i.c.v.-administered NmU. In the present study, motor activity was measured in two ways, such that horizontal locomotor activity (i.e. full transits across the cage) was separated from generalised motor activation (i.e. total beam breaks). NmU did not affect cage transits, suggesting that the NmU-induced increase in motor activity reported here and that in the literature (Nakazato et al. 2000; Hanada et al. 2001; Wren et al. 2002) do not represent directional movement but may result from induction of behaviours such as grooming.

Intense grooming behaviour in rats is characteristic of the stress response (Dunn et al. 1981) and is activated by CRH (Jones et al. 1998). Given the discrete localisation of NMU2R in the PVN, a major output centre of CRH, it is speculated that $\mathrm{NmU}$ activates grooming via $\mathrm{CRH}$ release from the PVN. In agreement, Hanada et al. (2001) showed a reduction in NmU-induced grooming and locomotor activity following anti-CRH $\operatorname{IgG}$ and $\alpha$-hCRH, and an absence of NmU-induced locomotor activity in the CRH knockout (KO) mouse. Further, Wren et al. (2002), showed NmU-induced grooming after direct injection to the PVN. However, it should be considered that NmU may affect $\mathrm{CRH}$, or other output systems, outside of the hypothalamus to cause its marked behavioural effects. Alternative sites of action of $\mathrm{NmU}$ are suggested in this discussion.

The widespread localisation of NmU fibres in hypothalamic nuclei make it ideally positioned to affect multiple hypothalamic output systems. In this study, we evaluated a "snap shot" of NmU-induced neuroendocrine changes at a single time point (20 min post-dose). Doses of $\mathrm{NmU}$ were equivalent to those used in behavioural studies. Centrally administered $\mathrm{NmU}$ increases plasma ACTH, corticosterone, arginine vasopressin and oxytocin (Ozaki et al. 2002; Wren et al. 2002). Here we extended these findings by showing a dose-related reduction in plasma prolactin following $\mathrm{NmU}(0.3-3 \mu \mathrm{g})$. Similar reductions in plasma prolactin levels are seen following i.c.v.-administered
orexin-A (Hagan et al. 1999; Jones et al. 2001) and suggest that these neuropeptides may be involved in the inhibitory control of prolactin. One candidate for this role is DA, which when released from DA neurons in the tuberoinfundibular pathway potently inhibits prolactin release from the pituitary (Ben-Jonathon et al. 1989). Plasma corticosterone levels were not affected by $\mathrm{NmU}$ (up to equivalent dose of $1.14 \mathrm{nmol}$ i.c.v.) in this study. In contrast, Ozaki et al. (2002) showed elevated plasma corticosterone and ACTH following a higher dose of NmU ( 3 nmol i.c.v.). The presence of $\mathrm{NmU}$ in the PVN may be required for effects on corticosterone as Wren et al. (2002) showed increased plasma corticosterone and ACTH levels following direct injection of a low dose of $\mathrm{NmU}$ $(0.3 \mathrm{nmol})$ to the PVN. If this were true, the relatively low doses of NmU used in the present study may not be sufficient to affect output from the PVN. Aside from the lack of effect on corticosterone, evidence described here and in the literature suggest that centrally administered $\mathrm{NmU}$ affects HPA function, and other neuroendocrine systems, via its actions on hypothalamic output systems.

Given that hypothalamo-pituitary output is influenced by DA, and receives significant input from limbic systems and various neurotransmitter systems, effects of $\mathrm{NmU}$ on the DA and 5-HT systems were investigated. The ratios of DA and 5-HT to their metabolites were measured in a range of brain areas. Using this technique, altered 5-HT and DA neurotransmission had previously been detected following i.c.v. administration of neuropeptides. For example, striatal and hypothalamic 5-HT metabolism are altered by orexin-B (Jones et al. 2001). NmU significantly elevated 5-HT levels in the frontal cortex and hypothalamus, with both increased levels of 5-HT and decreased levels of its metabolites in the hypothalamus and hippocampus, suggesting decreased 5-HT utilisation. The physiological significance of this effect requires further investigation, although a hypothalamic role for $\mathrm{NmU}$ is further implicated. The localisation of NmU-ir by in the substantia nigra and nucleus accumbens (Domin et al. 1987), together with inhibition of prolactin release from the pituitary, suggests a role for NmU in DA regulation. However, NmU did not affect the ratio of DA to its metabolites in any areas tested, suggesting an alternative mechanism for prolactin regulation by $\mathrm{NmU}$. More sensitive and anatomically discrete methods of measurement, e.g. microdialysis, will be of use in fully understanding the interactions between $\mathrm{NmU}$ and neurotransmitter systems, including the 5-HT system, in the brain.

Finally, to define anatomical substrates involved in the central actions of NmU, we measured FLI in the rat brain as a marker of neuronal activation in pre-defined brain regions. High levels of FLI in the nucleus accumbens and frontal cortex are consistent with the localisation of NMU2R mRNA in these regions and, together with effects on the 5-HT system, may indicate roles for $\mathrm{NmU}$ in sensory motor gating, arousal, attention and cognitive function. In agreement with Ivanov et al. (2002), high levels of FLI were observed in the central amygdala, an area that is associated with emotional learning and 
memory. Interestingly, the amygdala is the only area of rat brain expressing both NMU1R and NMU2R mRNA. A role for $\mathrm{NmU}$ in fear conditioning is worthy of further investigation. Fos expression in the central amygdala is also consistent with the effects of NmU on HPA function. The central nucleus of the amygdala contains CRH neurons which play a role in stress-induced ACTH and corticosterone release (Herman et al. 2003). Therefore, activation of the central nucleus of the amygdala may contribute towards the reported $\mathrm{NmU}$ effects on stress hormones.

Given the high levels of FLI in the frontal cortex and accumbens, and the stimulant-like effect of $\mathrm{NmU}$ on behaviours, effects on PPI (measured as \%PPI) of an acoustic startle stimuli were determined. However, $\mathrm{NmU}$ did not influence the amplitude of the startle response or $\%$ PPI. In retrospect, this is consistent with lack of changes to DA neurotransmission in any brain areas tested.

The lack of increased FLI in the hypothalamus is surprising at first glance and contradicts reports by others who showed FLI in the PVN, arcuate nucleus, supraoptic nucleus, lateral hypothalamic area and dorsomedial nucleus (Ozaki et al. 2002; Ivanov et al. 2002). This discrepancy may be explained by the discrete localisation of FLI in specific nuclei, the examination of which was beyond the scope of this study. To gain a further insight into brain areas activated by $\mathrm{NmU}$, a more detailed analysis of specific areas of interest, for example the hypothalamus, should be undertaken. Additionally, future studies should utilise alternative techniques to map neuronal substrates for effects of $\mathrm{NmU}$, for example, pharmacological magnetic resonance imaging.

In summary, this series of studies confirms and extends evidence for multiple roles for $\mathrm{NmU}$ and its receptors in the brain. We have shown a widespread distribution of NMU1R and NMU2R mRNA, showing that NmU exerts central effects through NMU2R, and possibly NMU1R. To extend the current understanding of centrally mediated effects of NmU, we showed effects of i.c.v.-administered $\mathrm{NmU}$ on 5-HT transmission in the hypothalamus; Fos expression in the frontal cortex, nucleus accumbens and amygdala; and plasma prolactin levels. These data are in agreement with a role for $\mathrm{NmU}$ in regulating hypothalamic output (Wren et al. 2002), but also suggest more diverse roles for NmU. In future studies, selective tool compounds acting at $\mathrm{NmU}$ receptors will help to determine roles for NMU1R and NMU2R in the pharmacological actions of $\mathrm{NmU}$.

Acknowledgements The authors would like to thank Dr. R. Ravid, Netherlands Brain Bank, The Netherlands, for arrangement/donation of brain tissue; Gillian Rennie for expert technical assistance and Karen Davis, Susan Barber, Jackie College, Jonathan Barford and Louise Chamberlain for surgical and technical assistance.

\section{References}

Ballesta J, Carlei F, Bishop AE, Steel JH, Gibson SJ, Fahey M, Hennessey R, Domin J, Bloom SR, Polak JM (1998) Occurrence and developmental pattern of neuromedin Uimmunoreactive nerves in the gastrointestinal tract and brain of the rat. Neuroscience 25:797-816

Ben-Jonathon N, Arbogast LA, Hyde JF (1989) Neuroendocrine regulation of prolactin release. Prog Neurobiol 33:399-447

Brown DR and Quito FL (1988) Neuromedin U octapeptide alters ion transport in porcine jejunum. Eur J Pharmacol 155:159-162

Cao CQ, Yu XH, Dray A, Filosa A, Perkins MN (2003) A pronociceptive role of neuromedin $U$ in adult mice. Pain 104:609616

Conlon JM, Domin J, Thim L, DiMarzo V, Morris HR, Bloom SR (1988) Primary structure of neuromedin $U$ from the rat. J Neurochem 51:988-991

Domin J, Ghatei MA, Chohan P, Bloom SR (1986) Characterization of neuromedin $U$ like immunoreactivity in rat, porcine, guineapig and human tissue extracts using a specific radioimmunoassay. Biochem Biophys Res Commun 140:1127-1134

Domin J, Ghatei MA, Chohan P, Bloom SR (1987) Neuromedin U - a study of its distribution in the rat. Peptides 8:779-784

Domin J, Yiangou YG, Spokes RA, Aitken A, Parmar KB, Chrysanthou BJ, Bloom SR (1989) The distribution, purification, and pharmacological action of an amphibian neuromedin U. J Biol Chem 264:20881-20885

Dunn AJ, Guild AL, Kramarcy NR, Ware MD (1981) Benzodiazepines decrease grooming in response to novelty but not ACTH or $\beta$-endorphin. Pharmacol Biochem Behav 15:605608

Fujii R, Hosoya M, Fukusumi S, Kawamata Y, Habata Y, Hinuma S, Onda H, Nishimura O, Fujino M (2000) Identification of neuromedin $\mathrm{U}$ as the cognate ligand of the orphan $\mathrm{G}$ proteincoupled receptor FM-3. J Biol Chem 275:21068-21074

Gardiner SM, Compton AM, Bennett T, Domin J, Bloom SR (1990) Regional hemodynamic effects of neuromedin $U$ in conscious rats. Am J Physiol 258:R32-R38

Hagan JJ, Leslie RA, Patel S, Evans ML, Wattam TA, Holmes S, Benham CD, Taylor SG, Routledge C, Hemmati P, Munton RP, Ashmeade TE, Shah AS, Hatcher JP, Hatcher PD, Jones DN, Smith MI, Piper DC, Hunter AJ, Porter RA, Upton N (1999) Orexin A activates locus coeruleus cell firing and increases arousal in the rat. Proc Natl Acad Sci U S A 96:10911-10916

Hanada R, Nakazato M, Murakami N, Sakihara S, Yoshimatsu H, Toshinai K, Hanada T, Suda T, Kangawa K, Matsukura S, Sakata T (2001) A role for neuromedin U in stress response. Biochem Biophys Res Commun 289:225-228

Hanada T, Date Y, Shimbara T, Sakihara S, Murakami N, Hayashi Y, Kanai Y, Suda T, Kangawa K, Nakazato M (2003) Central actions of neuromedin U via corticotropin-releasing hormone. Biochem Biophys Res Commun 311:954-958

Hashimoto T, Masui H, Uchida Y, Sakura N, Okimura K (1991) Agonistic and antagonistic activities of neuromedin U-8 analogs substituted with glycine or D-amino acid on contractile activity of chicken crop smooth muscle preparations. Chem Pharm Bull 39:2319-2322

Hedrick JA, Morse K, Shan LX, Qiao XD, Pang L, Wang S, Laz T, Gustafson EL, Bayne M, Monsma FJ (2000) Identification of a human gastrointestinal tract and immune system receptor for the peptide neuromedin U. Mol Pharm 58:870-875

Herman JP, Figueiredo H, Mueller NK, Ulrich-Lai Y, Ostrander MM, Choi DC, Cullinan WE (2003) Central mechanisms of stress integration: hierarchical circuitry controlling hypothalamo-pituitary-adrenocortical responsiveness. Front Neuroendocrinol 24:151-180

Hosoya M, Moriya T, Kawamata Y, Ohkubo S, Fujii R, Matsui H, Shintani Y, Fukusumi S, Habata Y, Hinuma S, Onda H, Nishimura O, Fujino M (2000) Identification and functional characterization of a novel subtype of neuromedin $\mathrm{U}$ receptor. J Biol Chem 275: 29528-29532 
Howard AD, Wang RP, Pong SS, Mellin TN, Strack A, Guan XM, Zeng ZZ, Williams DL, Feighner SD, Nunes CN, Murphy B, Stair JN, Yu H, Jiang QP, Clements MK, Tan CP, McKee KK, Hreniuk DL, McDonald TP, Lynch KR, Evans JF, Austin CP, Caskey CT, Van der Ploeg LHT, Liu QY (2000) Identification of receptors for neuromedin $U$ and its role in feeding. Nature 406:70-74

Ivanov TR, Lawrence CB, Stanley PJ, Luckman SM (2002) Evaluation of neuromedin $U$ actions in energy homeostasis and pituitary function. Endocrinology 143:3813-3821

Jones DN, Kortekaas R, Slade PD, Middlemiss DN, Hagan JJ (1998) The behavioural effects of corticotropin-releasing factorrelated peptides in rats. Psychopharmacology 138:124-132

Jones DN, Gartlon J, Parker F, Taylor SG, Routledge C, Hemmati P, Munton RP, Ashmeade TE, Hatcher JP, Johns A, Porter RA, Hagan JJ, Hunter AJ, Upton N (2001) Effects of centrally administered orexin-B and orexin-A: a role for orexin-1 receptors in orexin-B-induced hyperactivity. Psychopharmacology 153:210-218

Kojima M, Haruno R, Nakazato M, Date Y, Murakami N, Hanada R, Matsuo H, Kangawa K (2000) Purification and identification of neuromedin $U$ as an endogenous ligand for an orphan receptor GPR66 (FM3). Biochem Biophys Res Commun 276:435-438

Leslie RA, Moorman JM, Coulson A, Grahame-Smith DG (1993) Serotonin $2 / 1 \mathrm{C}$ receptor activation causes a localized expression of the immediate-early gene c-fos in rat brain: evidence for involvement of dorsal raphe nucleus projection fibres. Neuroscience 53:457-463

Malendowicz LK, Markowska A (1994) Neuromedins and their involvement in the regulation of growth, structure and function of the adrenal cortex. Histol Histopathol 9:591-601

Minamino N, Kangawa K, Matsuo H (1985) Neuromedin U-8 and U-25: novel uterus stimulating and hypertensive peptides identified in porcine spinal cord. Biochem Biophys Res Commun 130:1078-1085

Mondal MS, Date Y, Murakami N, Toshinai K, Shimbara T, Kangawa K, Nakazato M (2003) Neuromedin U acts in the central nervous system to inhibit gastric acid secretion via CRH system. Am J Physiol Gastrointest Liver Physiol 284:G963G969

Morley JE, Levine AS (1982) Corticotrophin releasing factor, grooming and ingestive behaviour in rats and mice. Life Sci 31:1459-1464

Nakazato M, Hanada R, Murakami N, Date Y, Mondal MS, Kojima M, Yoshimatsu H, Kangawa K, Matsukura S (2000) Central effects of neuromedin $U$ in the regulation of energy homeostasis. Biochem Biophys Res Commun 277:191-194

O'Harte F, Bockman CS, Abel PW, Conlon JM (1991) Isolation, structural characterization and pharmacological activity of dog neuromedin U. Peptides 12:11-15
Ozaki Y, Onaka T, Nakazato M, Saito J, Kanemoto K, Matsumoto T, Ueta Y (2002) Centrally administered neuromedin U activates neurosecretion and induction of c-fos messenger ribonucleic acid in the paraventricular and supraoptic nuclei of rat. Endocrinology 143:4320-4329

Paxinos G and Watson C (1986) The rat brain in stereotaxic coordinates. Academic, New York

Raddatz R, Wilson AE, Artymyshyn R, Bonini JA, Borowsky B, Boteju LW, Zhou SQ, Kouranova EV, Nagorny R, Guevarra MS, Dai M, Lerman GS, Vaysse PJ, Branchek TA, Gerald C, Forray C, Adham N (2000) Identification and characterization of two neuromedin $U$ receptors differentially expressed in peripheral tissues and the central nervous system. J Biol Chem 275:32452-32459

Sakura N, Ohta S, Uchida Y, Kurosawa K, Okimura K, Hashimoto T (1991) Structure-activity relationships of rat neuromedin $U$ for smooth muscle contraction. Chem Pharm Bull 39:2016-2020

Shan LX, Qiao XD, Crona JH, Behan J, Wang S, Laz T, Bayne M, Gustafson EL, Monsma FJ, Hedrick JA (2000) Identification of a novel neuromedin $U$ receptor subtype expressed in the central nervous system. J Biol Chem 275:39482-39486

Simpson JB, Epstein AN, Camardo JS Jr (1978) Localization of receptors for the dipsogenic action of angiotensin II in the subfornical organ of rat. J Comp Physiol Psychol 92:581-601

Steel JH, Van Noorden S, Ballesta J, Gibson SJ, Ghatei MA, Burrin J, Leonhardt U, Domin J, Bloom SR, Polak JM (1988) Localization of $7 \mathrm{~B} 2$, neuromedin $\mathrm{B}$, and neuromedin $\mathrm{U}$ in specific cell types of rat, mouse and human pituitary, in rat hypothalamus and in 30 human pituitary and extrapituitary tumors. Endocrinology 122:270-282

Sumi S, Inoue K, Kogire M, Doi R, Takaori K, Suzuki T, Yajima H, Tobe T (1987) Effect of synthetic neuromedin U-8 and U-25, novel peptides identified in porcine spinal cord, on splanchnic circulation in dogs. Life Sci 41:1585-1590

Szekeres PG, Muir AI, Spinage LD, Miller JE, Butler SI, Smith A, Rennie GI, Murdock PR, Fitzgerald LR, Wu HL, McMillan LJ, Guerrera S, Vawter L, Elshourbagy NA, Mooney JL, Bergsma DJ, Wilson S, Chambers JK (2000) Neuromedin U is a potent agonist at the orphan $\mathrm{G}$ protein-coupled receptor FM3. J Biol Chem 275:20247-20250

Tan CP, McKee KK, Liu Q, Palyha OC, Feighner SD, Hreniuk DL, Smith RG, Howard AD (1998) Cloning and characterization of a human and murine T-cell orphan G-protein-coupled receptor similar to the growth hormone secretagogue and neurotensin receptors. Genomics 52:223-229

Wren AM, Small CJ, Abbott CR, Jethwa PH, Kennedy AR, Murphy KG, Stanley SA, Zollner AN, Ghatei MA, Bloom SR (2002) Hypothalamic actions of neuromedin U. Endocrinology 143:4227-4234

Yu XH, Cao CQ, Mennicken F, Puma C, Dray A, O’Donnell D, Ahmad S, Perkins M (2003) Pro-nociceptive effects of neuromedin $\mathrm{U}$ in rat. Neuroscience 120:467-474 